\title{
Presynaptic $\mathrm{Na}^{+}$Channels: Locus, Development, and Recovery from Inactivation at a High-Fidelity Synapse
}

\author{
Ricardo M. Leão, ${ }^{1}$ Christopher Kushmerick, ${ }^{1}$ Raphael Pinaud, ${ }^{1}$ Robert Renden, ${ }^{1}$ Geng-Lin Li, ${ }^{1}$ Holger Taschenberger, ${ }^{1}$ \\ George Spirou, ${ }^{2}$ S. Rock Levinson, ${ }^{3}$ and Henrique von Gersdorff ${ }^{1}$ \\ ${ }^{1}$ The Vollum Institute, Oregon Health and Science University, Portland, Oregon 97239, ${ }^{2}$ Sensory Neuroscience Research Center, West Virginia School of \\ Medicine Health Sciences Center, Morgantown, West Virginia 26506, and ${ }^{3}$ Department of Physiology and Biophysics, University of Colorado Medical \\ School, Denver, Colorado 80262
}

\begin{abstract}
$\mathrm{Na}^{+}$channel recovery from inactivation limits the maximal rate of neuronal firing. However, the properties of presynaptic $\mathrm{Na}^{+}$channels are not well established because of the small size of most CNS boutons. Here we study the $\mathrm{Na}^{+}$currents of the rat calyx of Held terminal and compare them with those of postsynaptic cells. We find that presynaptic $\mathrm{Na}^{+}$currents recover from inactivation with a fast, single-exponential time constant $\left(24^{\circ} \mathrm{C}, \tau\right.$ of $1.4-1.8 \mathrm{~ms} ; 35^{\circ} \mathrm{C}, \tau$ of $\left.0.5 \mathrm{~ms}\right)$, and their inactivation rate accelerates twofold during development, which may contribute to the shortening of the action potential as the terminal matures. In contrast, recordings from postsynaptic cells in brainstem slices, and acutely dissociated, reveal that their $\mathrm{Na}^{+}$currents recover from inactivation with a doubleexponential time course ( $\tau_{\text {fast }}$ of $1.2-1.6 \mathrm{~ms} ; \tau_{\text {slow }}$ of $80-125 \mathrm{~ms} ; 24^{\circ} \mathrm{C}$ ). Surprisingly, confocal immunofluorescence revealed that $\mathrm{Na}^{+}$ channels are mostly absent from the calyx terminal but are instead highly concentrated in an unusually long $(\approx 20-40 \mu \mathrm{m})$ unmyelinated axonal heminode. Outside-out patch recordings confirmed this segregation. Expression of $\mathrm{Na}_{\mathrm{v}} 1.6 \alpha$-subunit increased during development, whereas the $\mathrm{Na}_{\mathrm{v}} 1.2 \alpha$-subunit was not present. Serial EM reconstructions also revealed a long pre-calyx heminode, and biophysical modeling showed that exclusion of $\mathrm{Na}^{+}$channels from the calyx terminal produces an action potential waveform with a shorter halfwidth. We propose that the high density and polarized locus of $\mathrm{Na}^{+}$channels on a long heminode are critical design features that allow the mature calyx of Held terminal to fire reliably at frequencies near $1 \mathrm{kHz}$.
\end{abstract}

Key words: action potential; auditory; sodium; calyx of Held; high-frequency firing; heminode; nodes of Ranvier; presynaptic terminal

\section{Introduction}

Auditory brainstem neurons can fire action potentials (APs) at high frequencies and with remarkable precision, an ability thought to be crucial for the processing of sound signals (Oertel, 1999; Carr et al., 2001). The principal cells of the medial nucleus of the trapezoid body (MNTB) can follow afferent fiber stimulation rates of $200-300 \mathrm{~Hz}$ in postnatal day 9 (P9) rats (Borst et al., 1995), and some P14 principal cells can follow $800 \mathrm{~Hz}$ (Taschenberger and von Gersdorff, 2000). In mature mice, the calyx of Held nerve terminal can fire short AP trains at $1 \mathrm{kHz}$ without

Received Sept. 26, 2004; revised Jan. 14, 2005; accepted Feb. 11, 2005.

This research was supported by funds from the National Institutes of Health and Human Frontier Science Program. C.K. had partial support from a fellowship from Coordenação de Aperfeiçoamento de Pessoal de Nível Superior (Brazil) and a National Institutes of Health training grant. We thank K. Rowland and J. Thompson for performing calyx reconstructions and J. Grimes and B. Pope for expert technical assistance (National Center for Research Resources (enters of Biomedical Research Excellence grant). We thank B. Hille, E. McCleskey, P. Jonas, and L. Trussell for comments on a previous version of this manuscript.

Correspondence should be addressed to H. von Gersdorff, The Vollum Institute, L-474, Oregon Health and Science University, 3181 Southwest Sam Jackson Park Road, Portland, OR 97239-3098. E-mail: vongersd@ohsu.edu.

R. M. Leão's present address: Departamento de Fisiologia, Faculdade de Medicina de Ribeirão Preto, Universidade de São Paulo, Ribeirão Preto, 14049-900 São Paulo, Brazil.

C. Kushmerick's present address: Departamento de Fisiologia e Biofísica, Universidade Federal de Minas Gerais, Belo Horizonte, 31270-901 Minas Gerais, Brazil.

H. Taschenberger's present address: Department of Membrane Biophysics, Max Planck Institute for Biophysical Chemistry, D-37077 Göttingen, Germany.

DOI:10.1523/JNEUROSCI.3983-04.2005

Copyright $\odot 2005$ Society for Neuroscience $\quad$ 0270-6474/05/253724-15\$15.00/0 failure (Wu and Kelly, 1993). Moreover, in cats, the afferent fibers of the calyces of Held can fire sound-triggered APs in vivo at rates reaching $0.5-0.8 \mathrm{kHz}$ (Guinan and $\mathrm{Li}$, 1990; Spirou et al., 1990; Smith et al., 1998b). To maintain discharge rates at such high frequencies, a fast recovery from $\mathrm{Na}^{+}$channel inactivation is required (Kuo and Bean, 1994; Torkkeli and French, 2002). The biophysical properties, localization, and molecular identity of the $\mathrm{Na}^{+}$ channels on the calyx of Held synapse are, however, unknown.

Prolonged high-frequency firing tends to broaden APs and thus degrades their precise timing (Jackson et al., 1991; Geiger and Jonas, 2000). How does the calyx terminal avoid significant broadening of APs during high-frequency firing? What mechanisms are used to minimize $\mathrm{Na}^{+}$current recovery time? Moreover, high-frequency firing may lead to a large and simultaneous increase in free intraterminal $\left[\mathrm{Na}^{+}\right]_{\mathrm{i}}$ and $\left[\mathrm{Ca}^{2+}\right]_{\mathrm{i}}$, which would then render the $\mathrm{Na}^{+} / \mathrm{Ca}^{2+}$ exchanger ineffective in quickly extruding $\left[\mathrm{Ca}^{2+}\right]_{\mathrm{i}}$ (Reuter and Porzig, 1995). How does the calyx terminal circumvent this problem, which could lead to desynchronized transmitter release and perhaps to toxic increases in $\left[\mathrm{Ca}^{2+}\right]_{\mathrm{i}}$ via a reversal of the exchanger? In brief, what biophysical strategies and morphological specializations (Rowland et al., 2000 ) allow the calyceal axon and nerve terminal to fire reliably at the prodigious rates that have been observed in vivo?

Here we report that the rate of recovery from inactivation of calyx $\mathrm{Na}^{+}$currents accelerates during early postnatal develop- 
ment, in parallel with an increasing ability to cope with highfrequency firing. Immunocytochemical labeling revealed a steep gradient in $\mathrm{Na}^{+}$channel expression: strong staining on the precalyx axonal heminode and little to no staining on the calyx terminal. The expression of the node of Ranvier $\mathrm{Na}_{\mathrm{v}} 1.6$ subunit was found to increase during development, in accordance with an observed increase in axonal excitability with age. Biophysical modeling showed that exclusion of $\mathrm{Na}^{+}$channels from the calyx produces an AP with shorter half-width, making it more suitable to transmit precise timing information. We suggest that the high density of $\mathrm{Na}^{+}$channels on axonal heminodes ensures a fast, failsafe AP arrival at the calyx, thus conveying information about the onset of a sound stimulus, whereas the sharp segregation of $\mathrm{Na}^{+}$channels to axonal heminodes allows for rapid extrusion of $\left[\mathrm{Ca}^{2+}\right]_{\mathrm{i}}$ (via $\mathrm{Na}^{+} / \mathrm{Ca}^{2+}$ exchangers) at the calyx during bouts of prolonged high-frequency firing.

\section{Materials and Methods}

Brainstem slice preparation. Transverse (200 $\mu \mathrm{m}$ thick) brainstem slices were obtained from P5-P18 Sprague Dawley rats. After rapid decapitation, the brainstem was immersed in ice-cold low-calcium artificial CSF (aCSF) containing the following (in $\mathrm{mM}$ ): $125 \mathrm{NaCl}, 2.5 \mathrm{KCl}, 3.0 \mathrm{MgCl}_{2}$, $0.1 \mathrm{CaCl}_{2}, 25$ glucose, $25 \mathrm{NaHCO}_{3}, 1.25 \mathrm{NaH}_{2} \mathrm{PO}_{4}, 0.4$ ascorbic acid, 3 myo-inositol, and $2 \mathrm{Na}$-pyruvate, $\mathrm{pH} 7.3$ when bubbled with carbogen $\left(95 \% \mathrm{O}_{2}, \mathrm{CO}_{2} 5 \%\right)$. After cutting in a Leica (Nussloch, Germany) VT vibratome, the slices were transferred to an incubation chamber containing normal aCSF bubbled with carbogen and maintained at $37^{\circ} \mathrm{C}$ for 45 min and thereafter at room temperature (RT). The normal aCSF was the same as the low-calcium aCSF, except that $1.0 \mathrm{~mm} \mathrm{MgCl}_{2}$ and $2.0 \mathrm{~mm}$ $\mathrm{CaCl}_{2}$ were used.

Electrophysiology. Whole-cell patch-clamp recordings were performed in normal aCSF containing $200 \mu \mathrm{M} \mathrm{CdCl}{ }_{2}$ and $10 \mathrm{~mm}$ tetraethylammonium (TEA)-Cl. Currents were recorded at room temperature $\left(22-24^{\circ} \mathrm{C}\right)$ except in some experiments shown in Figure $1 B$, in which the bath temperature was increased to $34-36^{\circ} \mathrm{C}$ (average of $35^{\circ} \mathrm{C}$ ) with a Warner Instruments (Hamden, CT) TC-324B automatic temperature controller. The internal solution consisted of the following (in $\mathrm{mm}$ ): 90 Csmethanesulfonate, $20 \mathrm{CsCl}, 1 \mathrm{MgCl}_{2}, 5 \mathrm{Na}_{2}$-phosphocreatine, $40 \mathrm{HEPES}$, 10 TEA-Cl, 0.2 EGTA, 2 ATP-Mg, and 0.2 GTP, pH 7.3 with CsOH (310 $\mathrm{mOsm}$ ). Calyx terminals were identified visually by differential interference contrast (DIC) optics and sometimes by fluorescence of Lucifer yellow $(0.25 \mathrm{mg} / \mathrm{ml})$ added to the patch-pipette solution or by the presence, before the perfusion of cadmium, of a membrane capacitance jump after a depolarizing pulse (Taschenberger et al., 2002). Patch pipettes were pulled from soft thin-walled glass (World Precision Instruments, Sarasota, FL), were coated with dental wax, and had an open tip resistance of 2.5-7 M $\Omega$. Series resistance (5-15 M $\Omega$ ) was electronically compensated by $75-90 \%$ (10 $\mu$ s lag). For postsynaptic principal cell recordings, pipettes had an open tip resistance of 1.5-3 $\mathrm{M} \Omega$, and the series resistance (2-5 M $\Omega$ ) was electronically compensated by $75-90 \%$ (10 $\mu \mathrm{s}$ lag). Data acquisition was controlled by Pulse software, and signals were recorded via an EPC-9 patch-clamp amplifier (both from HEKA Elektronik, Lambrecht, Germany). Electrophysiological data were analyzed with Pulse Fit (HEKA Elektronik), Igor Pro (WaveMetrics, Lake Oswego, OR), and Prism 3.0 (GraphPad Software, San Diego, CA) software. Differences were considered statistically significant when $p$ values were $<0.05$ by the unpaired Student's $t$ test.

Presynaptic APs were recorded in normal aCSF, using the fast currentclamp mode of the EPC-9 after adjusting the fast-capacitance cancellation while in cell-attached mode (Taschenberger and von Gersdorff, 2000). Current-clamp recordings were continued only if the initial uncompensated $R_{\mathrm{s}}$ was $<10 \mathrm{M} \Omega$. Pipette solution for measuring presynaptic APs consisted of the following (in $\mathrm{mm}$ ): $110 \mathrm{~K}$-gluconate, $30 \mathrm{KCl}, 1$ $\mathrm{MgCl}_{2}, 10$ HEPES, 0.2 EGTA, $2 \mathrm{Mg}$-ATP, $0.5 \mathrm{GTP}$, and $10 \mathrm{Na}_{2^{-}}$ phosphocreatine, $\mathrm{pH} 7.3$ with $\mathrm{KOH}$. Outside-out patch recordings also used this internal solution for recording $\mathrm{Na}$ and $\mathrm{K}$ currents, whereas isolated $\mathrm{Na}$ currents were recorded using the Cs and TEA-based internal solution, with $200 \mu \mathrm{M} \mathrm{CdCl}{ }_{2}$ and $10 \mathrm{~mm}$ TEA-Cl in the aCSF. Presynaptic APs were elicited by afferent fiber stimulation. After establishing the whole-cell mode of recording, holding current was applied to set the membrane potential to $-80 \mathrm{mV}$.

Recovery from inactivation. A standard double-pulse protocol was used to measure recovery of $\mathrm{Na}$ currents from inactivation (Hille, 2001). The calyx and principal cell of the MNTB were pre-stepped to $-100 \mathrm{mV}$ for $50-100 \mathrm{~ms}$ to remove $\mathrm{Na}$ channel inactivation, stepped to the test potential $(-30 \mathrm{mV}$ except when otherwise stated) for 5 or $10 \mathrm{~ms}$ to measure the maximum $\mathrm{Na}$ current, stepped to the interpulse potential $(-100 \mathrm{mV}$ except when otherwise stated) for variable periods to allow recovery from inactivation to proceed, and finally stepped to the test potential to measure the fractional recovery from inactivation that occurred during the interpulse interval. Currents shown are normalized to the current available after the pre-step to $-100 \mathrm{mV}$, even when the interpulse potential was different from $-100 \mathrm{mV}$. When measuring recovery from inactivation at $-80 \mathrm{mV}$ and especially $-60 \mathrm{mV}$, there was significant steady-state inactivation at the interpulse potential, and thus the currents did not recover to $100 \%$. A single-exponential function was fit to the recovery from inactivation of the presynaptic $\mathrm{Na}$ current. The time constants obtained from these fits give a first estimate of the time course of recovery of the underlying $\mathrm{Na}$ conductance.

Measured Na current amplitudes can be subject to errors because of series resistance. Negative current passing through the series resistance makes the membrane potential positive relative to the pipette potential, causing a drop in the driving force for $\mathrm{Na}$. Because the size of the series resistance error depends on the size of the underlying conductance change, these effects will not be fixed during a recovery from inactivation protocol. Rather, they will be relatively small after very short recovery periods (when Na current is small) and larger after long recovery periods (when Na current is large). This differential effect distorts the time course of recovery of the Na current relative to that of the underlying $\mathrm{Na}$ conductance. We thus corrected the currents for changes in driving force according to the procedure described by Traynelis (1998) for synaptic currents. Current amplitudes were scaled by a factor, $K$, given by $K=$ $\left(V_{\mathrm{c}}-V_{\text {rev }}\right) /\left(V_{\mathrm{c}}-I R_{\mathrm{s}}-V_{\text {rev }}\right)$, where $V_{\mathrm{c}}$ is the command potential, $V_{\text {rev }}$ is the calculated reversal potential for $\mathrm{Na}, I$ is the current at any point in time, and $R_{\mathrm{s}}$ is the uncompensated series resistance. To test this method, $\mathrm{Na}$ currents from three calyces obtained from a P11 rat were recorded during recovery from inactivation. In control, the current amplitude ranged from 3 to $9 \mathrm{nA}$, and, after addition of $200 \mathrm{~nm}$ TTX, the current was reduced to $0.3-0.6 \mathrm{nA}$. For the uncorrected data, the time constant of recovery from activation was $0.47 \pm 0.12 \mathrm{~ms}$. After series resistance correction, these values increased to $0.80 \pm 0.16 \mathrm{~ms}$. In TTX, the time constants for recovery from inactivation was $0.89 \pm 0.09 \mathrm{~ms}$. Thus, the procedure used corrects most of the difference observed between control (when series resistance errors are considerable) and in TTX (when series resistance errors are predicted to be small). This correction procedure results in recovery from inactivation time constants that are $36.7 \pm 10 \%$ longer (slower) than those observed in the raw data ( $n=17$ calyces).

Series resistance voltage errors could also distort the measured rates of recovery from inactivation if the open probability of the $\mathrm{Na}$ channels was not saturated during the test depolarizations. We tested this possibility by measuring recovery from inactivation in the same cell using test depolarizations to $-30 \mathrm{mV}$ (the apparent peak of the $I-V$ curve) or $-10 \mathrm{mV}$. Under these conditions, the measured rates of recovery of the currents were not different $(1.76 \pm 0.07$ vs $1.77 \pm 0.13 \mathrm{~ms} ; \mathrm{P} 6-\mathrm{P} 8 ; n=4)$.

Preparation of dissociated cells. Isolated neurons from rat MNTB (P8P10) were freshly dissociated using enzyme treatment and trituration in a procedure modified from Raman and Bean (1997) and Kanold and Manis (1999). Briefly, 300- $\mu \mathrm{m}$-thick transverse brainstem slices were cut in ice-cold low-calcium aCSF and incubated in MEM (buffered with 20 mM HEPES) containing $40 \mathrm{U} / \mathrm{ml}$ papain (Worthington, Freehold, NJ), 1 mM cysteine, and $0.5 \mathrm{~mm}$ EGTA $\left(31^{\circ} \mathrm{C}, 20 \mathrm{~min}\right)$. After the digestion was blocked by adding trypsin inhibitor $(1 \mathrm{mg} / \mathrm{ml})$, the MNTB was microdissected out under a dissecting scope, transferred to aCSF buffered with $10 \mathrm{~mm}$ HEPES, and triturated with a fire-polished Pasteur pipette. Then the suspension of cells was transferred to the recording chamber, and the cells were allowed to settle for $30 \mathrm{~min}$. The chamber was perfused with 
normal aCSF with $10 \mathrm{~mm}$ TEA-Cl and $200 \mu \mathrm{M} \mathrm{CdCl}_{2}$ included to block $\mathrm{K}^{+}$and $\mathrm{Ca}^{2+}$ current. In voltage-clamp recordings the holding membrane potential was $-70 \mathrm{mV}$. The series resistance in whole-cell recordings was $6.8 \pm 1.5 \mathrm{M} \Omega(n=11)$ and was compensated by $90 \%(100 \mu \mathrm{s}$ lag). The resting capacitance was $16.4 \pm 3.4 \mathrm{pF}(n=11)$. The pipette solution was the same as for slice recordings of postsynaptic $\mathrm{Na}^{+}$ currents.

Afferent fiber stimulation thresholds. A bipolar tungsten stimulation electrode (parallel $80 \mu \mathrm{m}$ wires, $200 \mu \mathrm{m}$ apart; Frederick Haer Company, Bowdoinham, ME) was placed across the midline fiber tract, and voltage stimulation was delivered $(100 \mu$ s duration, $0.1 \mathrm{~Hz})$ using an IsoFlex stimulator driven by a Master 8 pulse generator (A.M.P.I., Jerusalem, Israel). Patch pipettes with resistances of 2-3 $M \Omega$ filled with recording saline were pressed against MNTB principal cells to form loose seals of $8-12 \mathrm{M} \Omega$. The fiber tract was then stimulated at $20-25 \mathrm{~V}$ at $0.1 \mathrm{~Hz}$, and cells with intact calyx inputs were identified by the presence of extracellular APs with appropriate kinetics and timing after the stimulation artifact. The same bipolar stimulation electrode was used for all of these recordings. The AP threshold was determined by decreasing stimulation voltage and monitoring the extracellular APs until failure occurred. The closest value of voltage above threshold within the range of $0.2-0.9 \mathrm{~V}$ was reported as the threshold. Thus, the threshold was determined with a resolution of $<0.9 \mathrm{~V}$. The extracellular AP size was invariant above threshold to increases in stimulation voltage, indicating that a unitary AP was being evoked (Bergsman et al., 2004). Sample sweeps were filtered at $3 \mathrm{kHz}$.

Computational modeling. The calyx reconstruction used in modeling studies was taken from an adult cat. Globular bushy cells in the cat express the putative calcium binding protein PEP-19 (peptide protein 19 ) in all cellular compartments, and MNTB cells do not express this protein (Spirou and Berrebi, 1996; Berrebi and Spirou, 1998). Therefore, one is able to visualize morphological details of the calyx without it being obscured by the postsynaptic cell. We reconstructed the calyx using Neurolucida software, interfaced with a motorized stage and Z-position readout on an upright microscope (MicroBrightField, Colchester, VT). The reconstructed geometry was imported into the neuronal simulation software NEURON (Hines and Carnevale, 2001). Large stalks, narrow necks, and swellings (see terminology by Rowland et al., 2000) were modeled as cylinders that were linked by the software. Model Na ${ }^{+}$channels and $\mathrm{K}^{+}$ channels $\left[G_{\mathrm{K}}=0.15 \mathrm{~S} / \mathrm{cm}^{2}\right.$, high-voltage activated Kv3.1-type; localized to the calyx (Dodson et al., 2003)] taken from Wang et al. (1998) were placed on the simulated calyx. A previously recorded calyx action potential was fed into an ideal voltage clamp placed in the heminode $10 \mu \mathrm{m}$ from the start of the calyx structure. The resulting changes in the calyx membrane potential were measured at different locations and different values of $\mathrm{Na}^{+}$conductance. The calculated changes in AP waveform (i.e., slight increase in height and half-width with increasing $\mathrm{Na}^{+}$channel density) were almost identical at different distal parts of the calyx structure.

We also tested the reconstructed calyx model using standard HodgkinHuxley-type channels adjusted to $25^{\circ} \mathrm{C}$ (data not shown). The results were qualitatively very similar as for the simulation described above. Thus, the conclusions we draw do not depend on the precise biophysical properties of the model channels. We also modeled the calyx as a simplified structure: a single cylinder implemented as a $0.4-\mu \mathrm{m}$-long, $40-\mu \mathrm{m}-$ diameter hollow cylinder of membrane. At the far end, the cylinder is closed. At the axon end, the diameter of the cylinder decreases to $5 \mu \mathrm{m}$, and then the structure continues as a cylinder of constant $5 \mu \mathrm{m}$ diameter to represent the attached axon. Hodgkin-Huxley-type channels were placed in this model calyx with default values for $G_{\mathrm{K}}$ and $G_{\text {Leak }}$ and different values of $G_{\mathrm{Na}}: 0,0.06$ [approximately the squid giant axon $\mathrm{Na}^{+}$ conductance necessary for high-frequency firing (Clay, 1998)], and 0.25 $\mathrm{S} / \mathrm{cm}^{2}\left[\sim 0.25\right.$ of the rat node of Ranvier $\mathrm{Na}^{+}$conductance (Hille, 2001)]. Simulations using this simplified calyx (a single thin cylinder; perhaps more appropriate for the cup-shaped P9 or younger calyces) and the more realistic model adult calyx composed of several different thin cylinders (see Fig. $10 \mathrm{~F}$ ) were essentially identical when APs were calculated at the tip of calyx structures, indicating that the conclusions con- cerning the changes in AP waveform with increasing $G_{\mathrm{Na}}$ in the calyx do not depend strongly on the exact morphological model of the terminal.

Immunofluorescence. Brainstem slices (100-200 $\mu \mathrm{m}$ thick) were cut as for electrophysiology and fixed with $4 \%(w / v)$ paraformaldehyde in phosphate buffer $(\mathrm{PB})$ for $1 \mathrm{~h}$. Free-floating sections were then washed in $0.1 \mathrm{M}$ PB (three washes for $10 \mathrm{~min}$ each) and incubated in a blocking buffer solution (BB), which consisted of $0.3 \%(\mathrm{v} / \mathrm{v})$ Triton X-100, $0.4 \%$ $(\mathrm{v} / \mathrm{v})$ normal goat serum, and $0.2 \%(\mathrm{w} / \mathrm{v})$ bovine $\gamma$-globulin for $1 \mathrm{~h}$ at RT. Subsequently, sections were washed in PB (three time for $10 \mathrm{~min}$ each) and incubated overnight in solutions containing anti-synaptic vesicle protein 2 (SV2) (1:100 in BB; mouse monoclonal; Developmental Studies Hybridoma Bank, University of Iowa, Iowa City, IA) and 1:100 dilutions (in BB) of the primary anti- $\mathrm{Na}^{+}$channel antibodies. Pan-specific rabbit polyclonal antibodies (PAN) were generated against a conserved sequence present in all vertebrate $\mathrm{Na}_{\mathrm{v}} 1$ isoforms (Dugandzija-Novakovic et al., 1995). Anti-peptide rabbit polyclonal antibodies against the $\mathrm{Na}_{\mathrm{v}} 1.2$ isoform were developed against a unique sequence in the $\mathrm{Na}_{\mathrm{v}} 1.2 \mathrm{C}$ terminus (Gong et al., 1999). Anti-peptide rabbit polyclonal antibodies against $\mathrm{Na}_{\mathrm{v}} 1.6$ were generated against a synthetic peptide corresponding to a unique sequence in the large intracellular domain I-II loop of $\mathrm{Na}_{\mathrm{v}} 1.6$ (Krzemien et al., 2000).

The following day, sections were thoroughly washed in $\mathrm{PB}$ (three times for $10 \mathrm{~min}$ each) and incubated for $2 \mathrm{~h}$ at room temperature in solutions containing both a goat anti-rabbit IgG-Alexa 568-conjugated and a goat anti-mouse IgG-Alexa 488-conjugated fluorescent secondary antibodies (1:100; both from Molecular Probes, Eugene, OR). Excess unbound antibody was washed from sections in a series of three PB washes. Sections were then mounted onto Superfrost slides (Fisher Scientific, Houston, TX) in photobleaching-protective medium (Vectashield; Vector Laboratories, Burlingame, CA). Digital photomicrographs were acquired at a series of focal planes with a Nikon (Tokyo, Japan) PCM-2000 laser scanning confocal microscope. Plates were assembled using Adobe Photoshop software (Adobe Systems, San Jose, CA).

Immunocytochemistry. Animals were injected with an overdose of Nembutal (50 mg/kg, i.p.). Rats were perfused transcardially with $40 \mathrm{ml}$ of $0.1 \mathrm{M} \mathrm{PB}, \mathrm{pH} 7.4$, followed by $60 \mathrm{ml}$ of $4 \%$ paraformaldehyde in $0.1 \mathrm{M}$ $\mathrm{PB}$. Brains were removed, cryoprotected in a $30 \%$ sucrose solution, and fast frozen in a dry-ice/ethanol bath. Sections were cut at $30 \mu \mathrm{m}$ in the coronal plane using a cryostat and were directly mounted onto Superfrost slides (Fisher Scientific). All slides were stored at $-80^{\circ} \mathrm{C}$ until additional processing.

Slides were removed from the $-80^{\circ} \mathrm{C}$ freezer, and tissue was rehydrated for $20 \mathrm{~min}$ in $\mathrm{PB}$ at room temperature. Sections were then incubated in a $0.3 \%$ hydrogen peroxide solution in $0.1 \mathrm{M}$ PB for quenching of endogenous peroxidase activity. Slides were washed in PB (three times for 10 min each) and incubated in $\mathrm{BB}$ and subsequently in a solution containing the primary anti-Na channel antibodies as described above for immunofluorescence, except that incubations with the primary antibodies using this methodology were performed at $4^{\circ} \mathrm{C}$ in a humid chamber.

The following day, sections were washed in PB for 30 min and subsequently incubated in a goat anti-rabbit biotinylated antibody (Vector Laboratories) at a dilution of 1:200 in blocking solution at RT for $2 \mathrm{~h}$. Tissue was then rinsed for $30 \mathrm{~min}$ in $\mathrm{PB}$ and incubated in an avidinbiotin complex solution (1:100; Vector Laboratories) in $0.1 \mathrm{M} \mathrm{PB}$ for $2 \mathrm{~h}$ at room temperature and then washed in $\mathrm{PB}$. Immunostaining was visualized by tissue incubation in a filtered solution containing $0.03 \%$ diaminobenzidine and $0.15 \%$ nickel ammonium sulfate in $0.1 \mathrm{M} \mathrm{PB}$ to which $0.001 \%$ hydrogen peroxide had been added. Sections were usually incubated in this solution for $6 \mathrm{~min}$, after which period they were dehydrated in a series of alcohols, defatted, and coverslipped with Protocol (Fisher Scientific).

Immunocytochemical controls for both immunolabeling techniques were performed by preincubation of primary antibody with its peptide antigen at a molar ratio of 100:1 peptide to antibody for $3 \mathrm{~h}$, as well as by the omission of primary antibody. Both procedures led to absence of immunolabeling (data not shown).

Electron microscopy. One P14 rat pup, used in a previous study (Taschenberger et al., 2002), was processed for serial section electron and 
semithin section light microscopy. Briefly, the animal was perfused transcardially with a calcium-free Ringer's solution, followed by a mixture of $2 \%$ paraformaldehyde and $2.5 \%$ glutaraldehyde in $0.12 \mathrm{M}$ phosphate buffer. Thick sections were postfixed with $1 \%$ osmium tetroxide, stained with 2\% uranyl acetate, and flat embedded in Epon. A tissue block containing the MNTB and adjacent trapezoid body was serially sectioned. The first group of sections comprised alternating ultrathin $(5 \times 70 \mathrm{~nm})$ and semithin $(2 \times 500 \mathrm{~nm})$ sections, covering a depth of $20 \mu \mathrm{m}$. Two other groups of serial sections comprised ultrathin sections only, covering depths of $8.75 \mu \mathrm{m}(125 \times 70 \mathrm{~nm})$ and $7 \mu \mathrm{m}(100 \times 70 \mathrm{~nm})$. Photographs were taken at magnification of $1.5-2 \mathrm{~K}$, and montages of tissue sections were prepared for sections preceding and following each doublet of semithin sections or every fifth section for ultrathin-only series. To create a three-dimensional model of the calyceal axon, photographic negatives were scanned and imported into software for alignment and tracing of the axon, calyx, and myelin sheath [Align, Trace (Kristen Harris, Medical College of Georgia, Augusta, GA; www.synapses.mcg.edu)]. VRML (virtual reality modeling language) files were created (Trace) and viewed with a graphics program (Amapi Designer 7; Eovia, Mountain View, CA).

\section{Results}

Fast recovery from inactivation of presynaptic $\mathrm{Na}^{+}$currents

$\mathrm{Na}$ currents recorded in the calyx of Held activated and inactivated almost completely within $\sim 3 \mathrm{~ms}$ (Fig. 1). Although an analysis of the activation properties of this current may be impaired by the limited space- and voltage-clamp control, measurement of the inactivation and recovery of $\mathrm{Na}$ currents should be less compromised. A standard double-pulse protocol was used to study recovery from inactivation whereby two test pulses to -30 $\mathrm{mV}$ were separated by a variable recovery period, as can be seen in Figure $1 A$. In recordings from 22 calyces from $\mathrm{P} 6-\mathrm{P} 14$ rats, $\mathrm{Na}$ currents recovered almost completely $(98.2 \pm 0.6 \%)$ within 7.5 $\mathrm{ms}$, after a single-exponential time course with $\tau$ of $1.44 \pm 0.08$ $\mathrm{ms}$ at RT [ $\tau$ of $0.98 \pm 0.06 \mathrm{~ms}$ in the uncorrected raw data (see Materials and Methods); $V_{\mathrm{h}}$ of $-100 \mathrm{mV}$ ] (Fig. $1 B$ ). In three cells recorded at a more physiological temperature $\left(35^{\circ} \mathrm{C}\right)$, the recovery was complete $(99 \pm 0.11 \%)$ at $1.5 \mathrm{~ms}$ and had a singleexponential time course $(\tau$ of $0.50 \pm 0.06 \mathrm{~ms}$ ) (Fig. $1 B$ ). $\mathrm{Na}$ currents recorded from the calyx of Held were blocked by tetrodotoxin ( $3 \mu \mathrm{M}$; data not shown).

The kinetics of recovery from inactivation depended on the membrane potential during the recovery period (Fig. 1C). Time constants for recovery from inactivation were faster at hyperpolarized potentials ( $\tau$ of $0.68 \mathrm{~ms}$ at $-120 \mathrm{mV}$; $\tau$ of $2.4 \mathrm{~ms}$ at -80 $\mathrm{mV}$; and $\tau$ of $9.4 \mathrm{~ms}$ at $-60 \mathrm{mV}$ ). The steady-state inactivation curve of the presynaptic current was well fitted by a Boltzmann function $\left(V_{1 / 2}\right.$ of $-62 \pm 1 \mathrm{mV}$; slope factor of $\left.7.8 \pm 1 \mathrm{mV}\right)$. The P8-P10 calyx terminal has a resting membrane potential of approximately $-80 \mathrm{mV}$ (Borst et al., 1995), and this very negative resting membrane potential likely aids high-frequency firing by maintaining the recovery $\tau$ at a low value. In recordings with a particularly low series resistance, we could measure calyx Na currents with acceptable voltage control as assessed by the gradual activation of the current-voltage relationship (Fig. $1 B$, inset, P10 rat). In this case, recovery from inactivation occurred with a $\tau$ of $1.13 \mathrm{~ms}$, similar to that obtained in the other calyx recordings. This observation supports the notion that recovery from inactivation is less sensitive to the voltage-clamp control.

In an attempt to study kinetic properties of voltage-gated $\mathrm{Na}$ channels under improved voltage-clamp conditions, we pulled outside-out patches from calyx terminals. Surprisingly, we observed that most $(70 \% ; n=24$ patches) of the calyx outside-out patches did not have $\mathrm{Na}^{+}$currents, although they all had voltagedependent $\mathrm{K}^{+}$currents (Fig. $2 \mathrm{~A}$ ). Patches without $\mathrm{Na}^{+}$currents
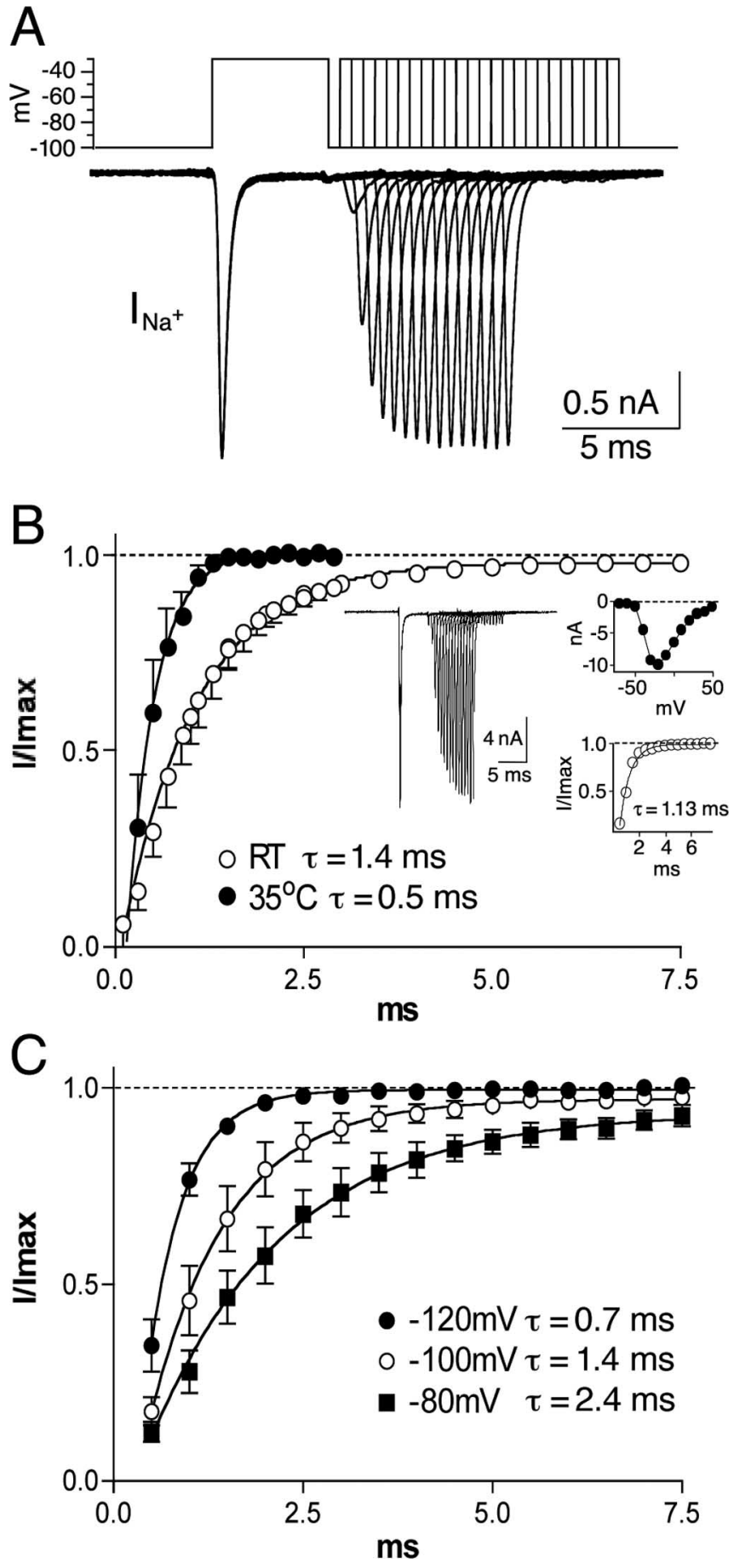

Figure 1. Rapid recovery from inactivation of calyx $\mathrm{Na}^{+}$channels. $A$, Pairs of presynaptic $\mathrm{Na}$ currents elicited at different time intervals from 0.5 to $7.5 \mathrm{~ms}$. $B$, Plot of the fraction of the $\mathrm{Na}$ current recovered after various time intervals (from 0.1 to $7.5 \mathrm{~ms}$ ) after the test pulse (see $\boldsymbol{A}$ ). Currents were recorded at RT $\left(22-24^{\circ} \mathrm{C} ; O\right)$ or at $35^{\circ} \mathrm{C}(\mathbf{O})$. The lines represent a singleexponential fit with time constant $\tau$. Left inset, An example of pairs of $\mathrm{Na}$ currents elicited as in $A$ from a P10 calyx. The $I-V$ relationship from the same calyx is shown in the top right inset and, in the bottom right inset, a plot of the fraction of $\mathrm{Na}$ current that recovered from inactivation at $-100 \mathrm{mV}$. The data were fit to a single-exponential function with $\tau$ of $1.13 \mathrm{~ms}$. C, Voltage dependence of the recovery from the inactivation. The fraction of $\mathrm{Na}$ current recovered is measured, using the same protocol as in $A$, but, after the first test pulse, various time intervals (from 0.1 to $7.5 \mathrm{~ms})$ at different voltages $(-80,-100$, and $-120 \mathrm{mV} ; n=6$ terminals from P10 P12) are given before the second test pulse. The lines are fits to single-exponential functions with time constants $\tau$ shown in the labels. The fraction of $\mathrm{Na}^{+}$current recovered increased with the amount of hyperpolarization. 

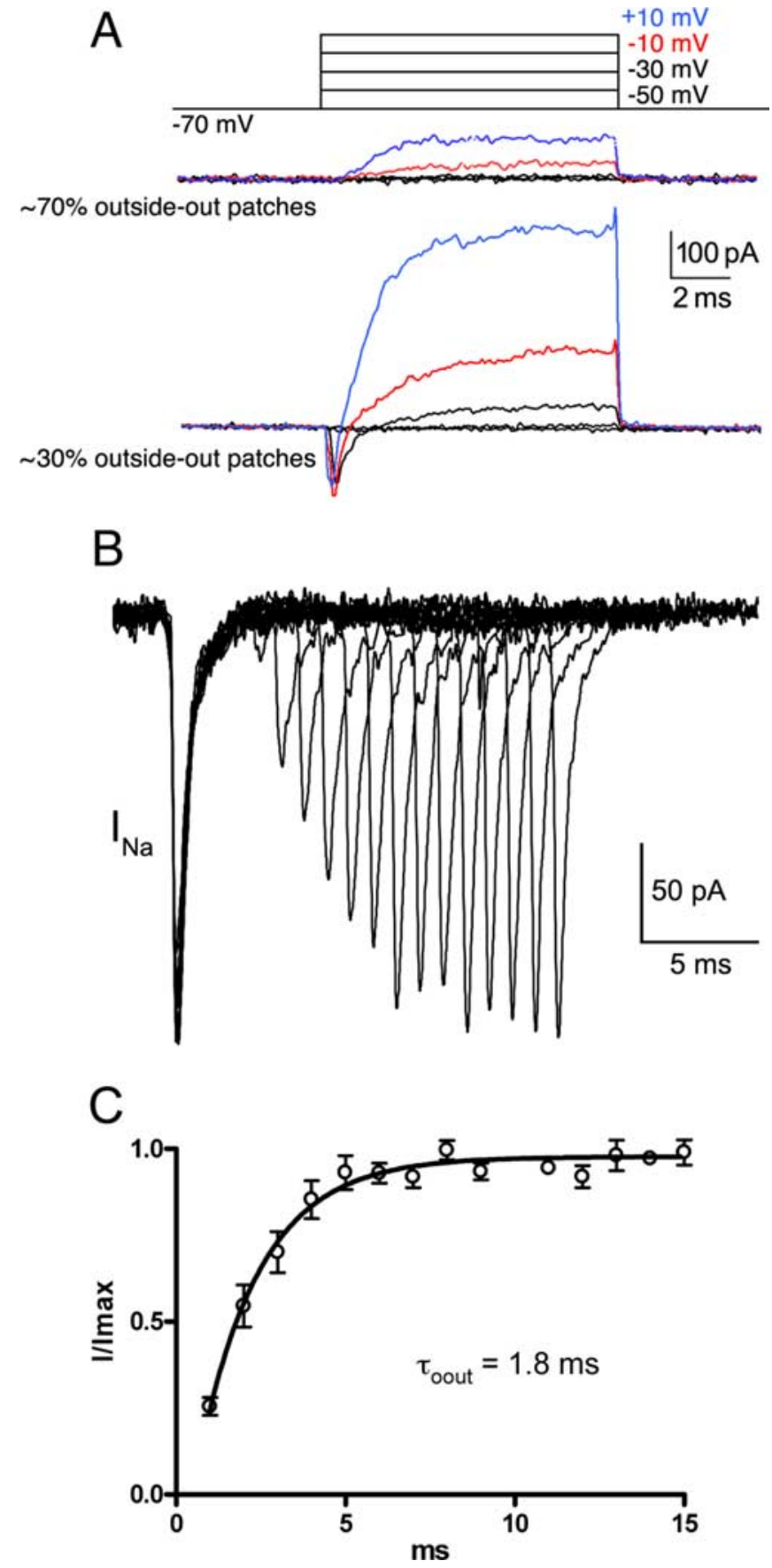

Figure 2. Presynaptic $\mathrm{Na}^{+}$currents in outside-out patches. $\boldsymbol{A}$, Two examples of calyx outside-out patches: one contained only potassium currents (top; representative of $\sim 70 \%$ of the patches) and the other with $\mathrm{Na}^{+}$and $\mathrm{K}^{+}$currents (bottom; representative of $\sim 30 \%$ of the patches). $\boldsymbol{B}$, Example of recovery from inactivation for an outside-out patch with unusually large $\mathrm{Na}^{+}$current amplitude. The recovery followed a single-exponential function with $\tau$ of $2.4 \mathrm{~ms}$ (RT; P11 rat). C, Recovery from inactivation from outside-out patches that contained $\mathrm{Na}^{+}$ currents. Patches were held for $-100 \mathrm{mV}$ for $50 \mathrm{~ms}$ before a $5 \mathrm{~ms}$ test pulse to $-30 \mathrm{mV}$ and kept at $-100 \mathrm{mV}$ for varying amounts of time (from 0.5 to $14 \mathrm{~ms}$ ) before testing the recovery from inactivation with a second $-30 \mathrm{mV}$ pulse. Data collected from seven patches that contained isolated $\mathrm{Na}^{+}$currents. Rat slices ranged in age from P8 to P13 (RT is $22-24^{\circ} \mathrm{C}$ ).

contained exclusively high-voltage threshold $\mathrm{K}^{+}$currents that activated at membrane voltages more than $-30 \mathrm{mV}$. In contrast, the $\mathrm{K}^{+}$current present in patches with $\mathrm{Na}$ current activated at more negative potentials, indicating the presence of low-voltageactivated K currents. Previous studies have shown that high- voltage threshold Kv3-type channels are exclusively located to the calyx terminal, whereas low-voltage threshold $\mathrm{K}^{+}$channels of the Kv1.2-type are located exclusively in the axonal heminode (Dodson et al., 2003; Ishikawa et al., 2003). Thus, the observed correlation of $\mathrm{Na}^{+}$current with low-threshold $\mathrm{K}^{+}$current and not high-threshold current suggests that presynaptic $\mathrm{Na}^{+}$channels are mostly excluded from the calyx terminal but are present on the axonal heminode. The presence of $\mathrm{K}^{+}$currents in patches without $\mathrm{Na}^{+}$currents also indicates that they were not attributable to vesicles formed in pipette tips by resealing of the inner membrane. Interestingly, $37 \%$ of the outside-out patches excised from pituitary "beads-on-a-string" nerve terminals also have no $\mathrm{Na}$ currents, suggesting that $\mathrm{Na}$ channels may be highly clustered in these terminals (Jackson and Zhang, 1995).

Some outside-out patches (30\%) displayed sizeable $\mathrm{Na}^{+}$currents $(260 \pm 107 \mathrm{pA} ; n=7)$ (Fig. 2 B). In these patches, the $\mathrm{Na}^{+}$ current $I-V$ relationship indicated good voltage control (data not shown). Recovery from inactivation in outside-out patches occurred with an average time constant of $\tau$ of $1.8 \pm 0.2 \mathrm{~ms}\left(V_{\mathrm{h}}\right.$ of $-100 \mathrm{mV} ; 24^{\circ} \mathrm{C} ; n=7$ ) (Fig. $2 \mathrm{C}$ ). This value was slightly larger than what we observed in whole-cell calyx recordings ( $\tau$ of 1.34 $\mathrm{ms}$ ) after series resistance correction of $\tau$. However, we also note that this larger time constant might be attributable to a disruption of the $\mathrm{Na}$ channel phosphorylation after patch excision (Johnston et al., 1999; Cantrell and Catterall, 2001). In addition, we note that patch excision has also been shown to change $\mathrm{Na}$ current activation and inactivation properties compared with whole-cell recordings (Jackson and Zhang, 1995; Shcherbatko et al., 1999). By comparison, recovery from inactivation in outsideout patches from mossy fiber boutons was much slower $[\tau$ of 3.6 $\mathrm{ms}$ at $V_{\mathrm{h}}$ of $-120 \mathrm{mV}$ (Engel and Jonas, 2004)] than that recorded here for the calyx of Held.

\section{Presynaptic $\mathrm{Na}^{+}$currents: developmental changes}

Presynaptic action potentials acquire a faster upstroke and shorter half-width as the calyx of Held matures (Taschenberger and von Gersdorff, 2000; Joshi and Wang, 2002). This may be attributable, in part, to developmental changes in the Na currents that contribute to the AP waveform. We observed that discharge failures often occurred in immature calyx synapses when the afferent fibers were challenged with high stimulation frequencies (e.g., $300 \mathrm{~Hz}$; average of two to three failures for P5-P7 calyces after 15 stimuli; $n=6$ ) (Fig. $3 A$ ), suggesting that the presynaptic $\mathrm{Na}$ currents were not optimized for high rates of firing. Note also that the P6 AP train rides on a small, depolarized plateau that is absent in the P13 train. This may be attributable to a lower density of $\mathrm{K}^{+}$channels and/or a slower inactivation rate for $\mathrm{Na}^{+}$ channels in immature terminals. To further investigate this hypothesis, we compared the inactivation properties of $\mathrm{Na}$ channels recorded from presynaptic terminals at P6-P8 and P10-P14.

We observed that $\mathrm{Na}^{+}$currents recorded in more mature terminals inactivated considerably faster than those in immature terminals (fast time constant of inactivation for P6-P7, $\tau_{\text {in }}$ of $0.63 \pm 0.06 \mathrm{~ms}, n=6$; for P10 $-\mathrm{P} 12$, $\tau_{\text {in }}$ of $0.34 \pm 0.02 \mathrm{~ms}, n=11$; $p<0.01 ; 22-24^{\circ} \mathrm{C}$ ) (Fig. $3 \mathrm{~B}$ ), which may contribute to the shorter presynaptic APs in mature calyces. Only $\mathrm{Na}^{+}$currents with relatively small and similar amplitudes (e.g., those during the first steps of recovery from inactivation or in the presence of $200 \mathrm{nM}$ TTX) were compared to exclude a distortion of the current waveform caused by series resistance errors (Zhang and Trussell, 1994). Peak $\mathrm{Na}^{+}$current amplitudes recorded from more mature terminals tended to be larger than those from immature terminals $[5.7 \pm 2.0 \mathrm{nA}$ for $\mathrm{P} 6-\mathrm{P} 9(n=10)$ vs $12.2 \pm 2.6 \mathrm{nA}$ for 
A

Presynaptic APs, $300 \mathrm{~Hz}$
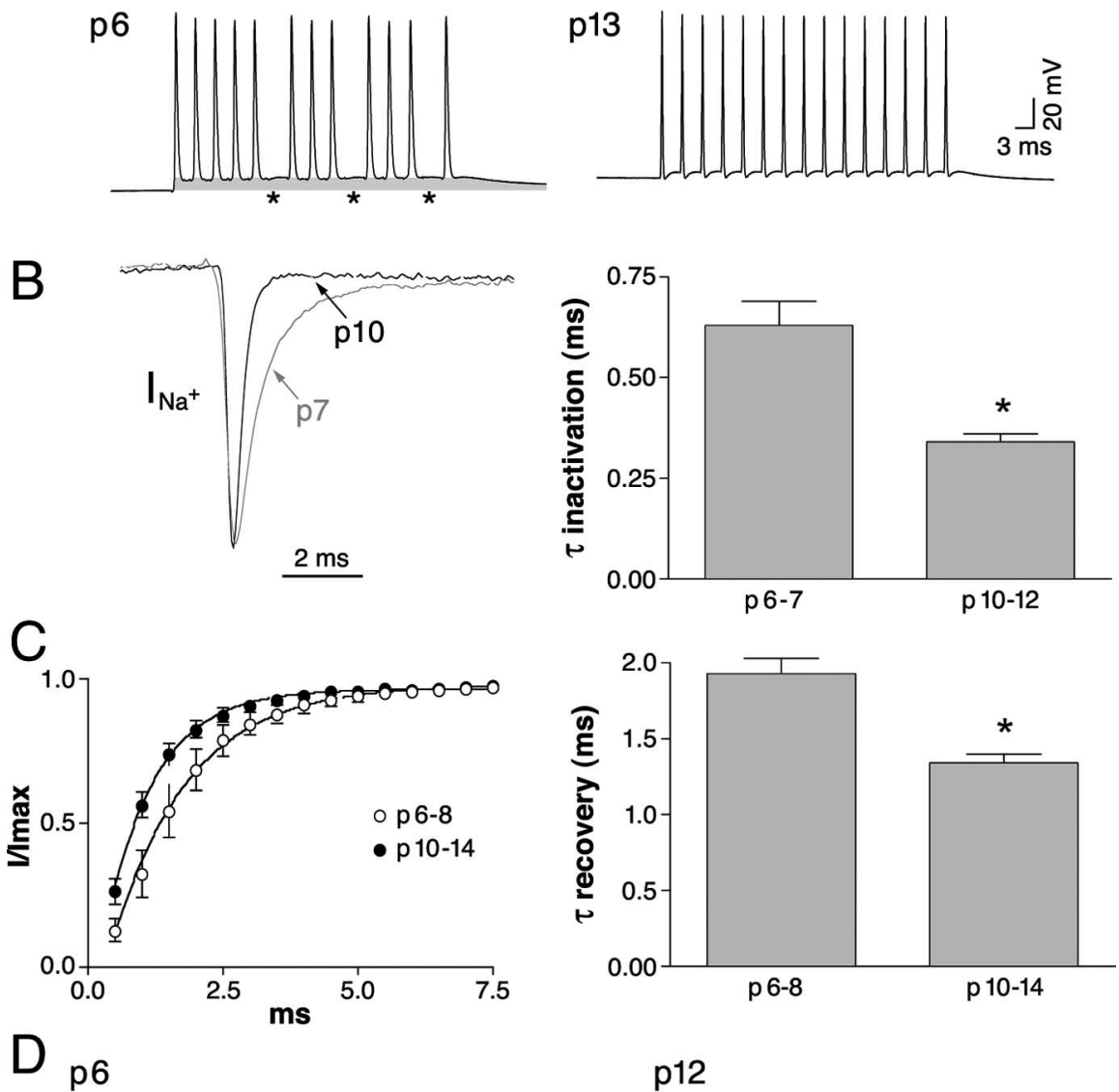

p12
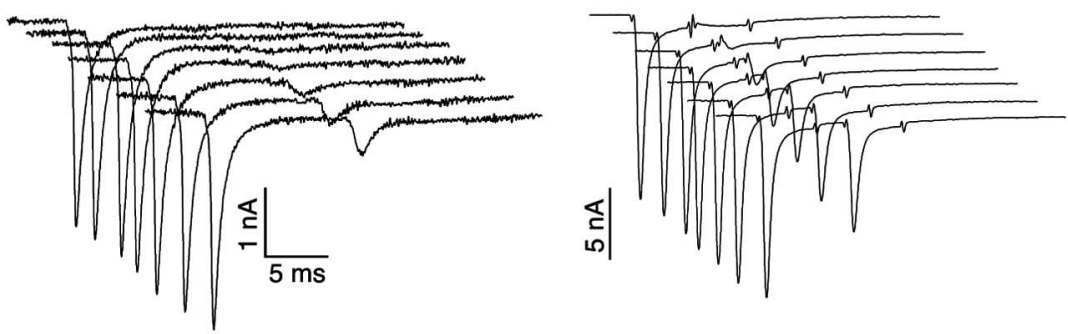

E
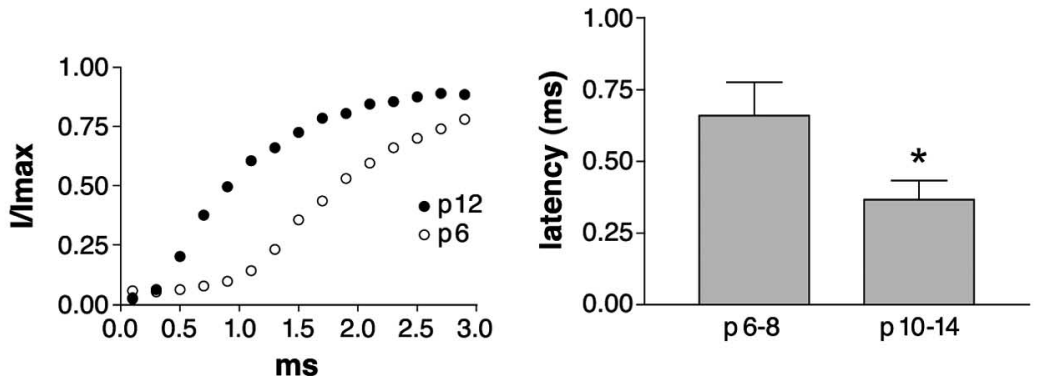

Figure 3. Maturation of presynaptic $\mathrm{Na}^{+}$currents. $A$,Action potential trains recorded in the calyx terminal triggered by afferent fiber stimulation. Examples from aP6anda P13 rat. Asterisks representfailuresinfiring of theaction potential during $300 \mathrm{~Hz}$ train of 15 stimulito the fibers in the trapezoid body. The gray area in the P6AP train marks a small depolarizing plateau that is absent at P13.B, $\mathrm{Na}^{+}$currents of more mature terminals inactivated more quickly. Left, Two peaknormalized traces of $\mathrm{Na}^{+}$currents recorded from a P7 and a P10 terminal. Right, Summary of the $\tau v$ values obtained by fitting the $\mathrm{Na}^{+}$current inactivation by a single-exponential function in thetwo age groups (P6-P7, $\tau$ of0.63 $\pm 0.06 \mathrm{~ms} ; \mathrm{P} 10-\mathrm{P} 12, \tau$ of $\left.0.34 \pm 0.02 \mathrm{~ms}^{*}{ }^{*} \mathrm{p}<0.01\right) . \mathrm{C}, \mathrm{Na}^{+}$currents recorded from more mature terminals recovered faster from inactivation than currents recorded in immatureterminals. Left, Recoveryfrom inactivation plotsfrom currents recorded from terminals of differentagegroups $(\mathbf{O}, \mathrm{P} 10-\mathrm{P} 14, n=10 ; 0$, $\mathrm{P} 6-\mathrm{P} 8, n=6)$. Curves represent fits to single-exponential functions. Right, Summary of the $R_{\mathrm{s}}$ corrected $\tau$ values obtained from the singleexponential fits (P6-P8, $\tau$ of $1.93 \pm 0.06 \mathrm{~ms} ; \mathrm{P} 10-\mathrm{P} 14, \tau$ of $\left.1.34 \pm 0.1 \mathrm{~ms} ;{ }^{*} p<0.05\right)$. D, Latency time decreases with age. Traces showing the recovery from inactivation of the $\mathrm{Na}^{+}$currents elicited every $0.2 \mathrm{~ms}$. Notethechange in latency for the firstappearance of the $\mathrm{Na}^{+}{ }^{+}$current with age (4th trace at P6 and 2nd trace atP12).E, Left, plot of the fraction of the $\mathrm{Na}^{+}$current recovered from the two terminals of $\boldsymbol{D}$ seen on a finer timescale. Right, Summary of the latency times obtained from the two age groups ( $0.6 \pm 0.12 \mathrm{~ms}$ for P6 $-\mathrm{P} 8 ; 0.28 \pm 0.07 \mathrm{~ms}$ for P10 $-\mathrm{P} 14 ;{ }^{*} p<0.05$ ).
P10-P14 $(n=11)]$, but the current amplitude was quite variable, and this difference was not significant ( $p=0.253$; MannWhitney nonparametric test). This variability in current amplitude for different calyces may be partly attributable to differences in axon lengths (cut during slicing) and partly attributable to differences in voltage-clamp quality. Such large currents may be necessary to quickly charge the large calyx membrane capacitor during the AP.

Apart from their faster inactivation, $\mathrm{Na}$ currents in mature calyces also recovered significantly faster from inactivation $(\tau$ of $1.34 \pm 0.1 \mathrm{~ms}, n=10, \mathrm{P} 10-\mathrm{P} 14$ vs $\tau$ of $1.93 \pm 0.06 \mathrm{~ms}, n=6$, P6-P8; $p<0.05$; measured at a recovery potential of -100 $\mathrm{mV}$ ) (Fig. 3C). These series resistance corrected values of $\tau$ (for a given age group) did not correlate with the peak amplitude of the Na currents (which ranged from 1.5 to $15 \mathrm{nA}$ for $\mathrm{P} 6-\mathrm{P} 8$ and from 2 to $25 \mathrm{nA}$ for P10-P14; see above). Recovery from inactivation started after an initial delay (latency) of $0.1-0.9 \mathrm{~ms}$ (Fig. 3D). This delay may reflect the time needed for the channel to move back to the closed state (deactivate) to be able to open again (Kuo and Bean, 1994). The length of this latency period depended on the age of the animal. It was significantly shorter in more mature synapses compared with immature ones $(0.28 \pm 0.07 \mathrm{~ms}$ in $\mathrm{P} 10-\mathrm{P} 14$ vs $0.6 \pm 0.12$ $\mathrm{ms}$ in $\mathrm{P} 6-\mathrm{P} 8$ ) (Fig. 3E).

\section{Developmental changes in axonal excitability} Developmental changes in axonal $\mathrm{Na}$ channel properties and density may affect the excitability of the afferent fibers that give rise to the calyx of Held. We thus stimulated the afferent fibers to the MNTB at $0.1-10 \mathrm{~Hz}$ to measure extracellular AP currents generated at the calyx of Held synapse during postnatal development with a loose-seal patch pipette (Fig. 4). Extracellular recordings of APs (or action currents) provide a relatively noninvasive examination of AP and synaptic timing with very high temporal resolution (Guinan and Li, 1990; Barnes-Davies and Forsythe, 1995; Borst et al., 1995; Smith et al., 1998b). Both presynaptic and postsynaptic APs can be detected at the MNTB, as evidenced by the fact that decreasing extracellular divalent ions to $0.1 \mathrm{mM} \mathrm{Ca}^{2+}$ and 0 $\mathrm{Mg}^{2+}$ selectively eliminated the postsynaptic waveform and also significantly reduced the presynaptic AP stimulation threshold (from 10.5 V to 9.3 V; $p=0.013$; paired $t$ test; $n=4$ cells; see supplemental material, available at www.jneurosci.org), perhaps by relieving divalent screening of 

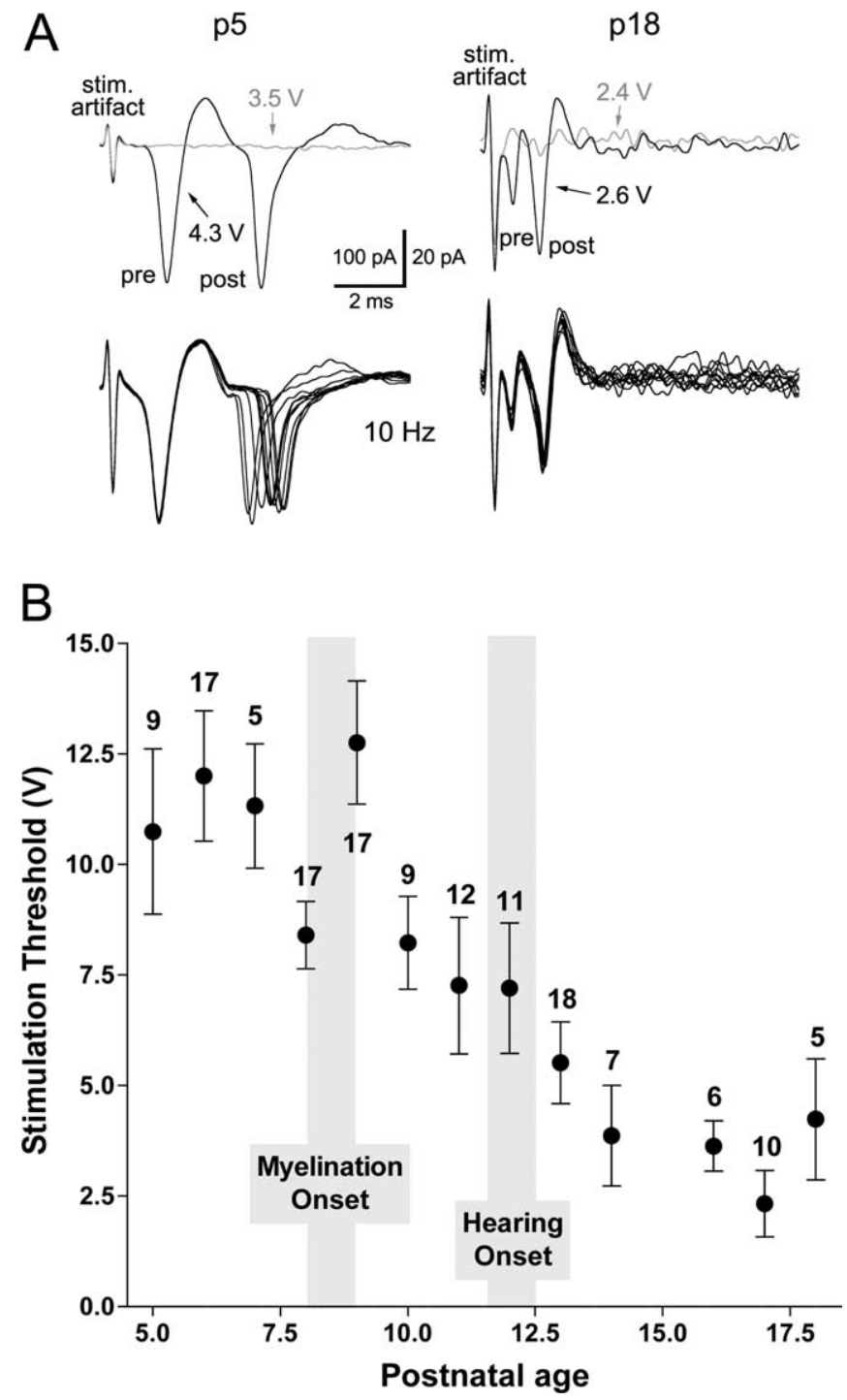

Figure 4. Afferent fiber excitability during development. $\boldsymbol{A}$, Extracellular action potential recordings at the calyx of Held-principal cell synapse in young (P5) and mature (P18) rat MNTB. Top row shows synaptic waveforms above (black) and below (gray) stimulus threshold, with stimulation voltages indicated. Older animals showed prominent sharpening of AP waveforms and decreased synaptic delay. The bottom row shows $10 \mathrm{~Hz}$ stimulation at $1-4 \mathrm{~V}$ above threshold in the same cells (10 successive stimuli). Presynaptic AP waveforms in both young and mature synapses show no jitter, whereas postsynaptic timing becomes more precise in older animals (1.9 ms jitter at P5; $225 \mu \mathrm{s}$ at P18). B, Stimulation threshold versus age for P5-P18 rat slices. Sample size (number of MNTB cells) is indicated above each marker. Error bars are SEM. Approximate start dates for axon myelination and hearing onset (ear canal opening) are indicated by shaded bars.

$\mathrm{Na}^{+}$channels (Hille et al., 1975). The threshold for AP generation was very sharp, with very small (e.g., $0.2 \mathrm{~V}$ ) changes in voltage resulting in a shift from no responses (subthreshold) (Fig. $4 \mathrm{~A}$, top gray traces) to fully reliable AP generation (suprathreshold) (Fig. $4 A$, black traces). An increase in stimulation voltage did not result in any change to the shape or timing of the AP current, suggesting that we were activating only one afferent input (Bergsman et al., 2004). Shown are sample traces from recordings in young (P5) and mature (P18) rats. Note that the presynaptic and postsynaptic "AP waveforms" are shorter in P18 than in P5. Latencies between peaks of the presynaptic and postsynaptic spikes decreased significantly from P5 to P18 (3.2 \pm 0.1 vs $0.92 \pm 0.1$ $\mathrm{ms} ; p=0.0001$; paired $t$ test). Postsynaptic timing jitter, mea- sured as the difference in fastest and slowest postsynaptic waveform peaks during a 10 stimuli train at $10 \mathrm{~Hz}$, was also greatly reduced during development (e.g., $1.9 \mathrm{~ms}$ in P5 and $225 \mu$ s in P18 for Fig. $4 \mathrm{~A}$ ). These developmental changes are all consistent with previous whole-cell AP recordings (Taschenberger and von Gersdorff, 2000)

AP threshold of MNTB afferent fibers decreased with age from an average of 10-15 V (P5-P7) to <5 V (P16-P18) (Fig. 4B). A coordinated series of maturational events occurs in the second postnatal week. The onset of myelination occurs at approximately P8-P9 in rat MNTB (E. Friauf, personal communication), $\mathrm{Na}^{+}$channels show an increase in inactivation speed by P10 (Fig. 3B), hearing begins by P12 (Blatchley et al., 1987), and the morphology of the rat calyx becomes similar to that of adults by P14 (Kandler and Friauf, 1993). When stimulation thresholds are grouped according to these developmental milestones (P5$\mathrm{P} 9, \mathrm{P} 10-\mathrm{P} 12$, and P14-P18), the mean thresholds of the three groups are significantly different from each other $(p<0.0001$; Kruskal-Wallis ANOVA). We suggest that this decrease in AP threshold is attributable to a combination of functional changes that occur during development: improved myelination of the axon, which reduces axonal capacitance, possible changes in axonal diameter, and insertion and clustering of $\mathrm{Na}^{+}$channels at the nodes of Ranvier (Salzer, 2003).

\section{Comparison with postsynaptic $\mathrm{Na}^{+}$currents}

Using the same protocols used to study calyx currents, we found that $\mathrm{Na}^{+}$currents in the MNTB principal cells show a doubleexponential recovery from inactivation with $\tau_{\text {fast }}$ of $1.23 \pm 0.04$ $\mathrm{ms}$ and $\tau_{\text {slow }}$ of $125 \pm 28 \mathrm{~ms}$ (Fig. $5 \mathrm{~A}, \mathrm{~B}$ ). The slow time constant did not change during development. However, the fraction of slow recovery from inactivation did decrease during development from $12 \pm 1.7 \%$ in P5-P6 to $4 \pm 1.4 \%$ in P8-P12 (Fig. $5 C$ ). A similar developmental change in principal cell $\mathrm{Na}^{+}$currents is also seen in the mouse MNTB (Ming and Wang, 2003).

A striking difference between presynaptic and postsynaptic $\mathrm{Na}^{+}$currents is the presence of a TTX-sensitive persistent (i.e., non-inactivating) component in principal cells (Fig. 5D). This current was on average $9.2 \pm 1.3 \%(0.5 \pm 0.06 \mathrm{nA})$ of the peak $\mathrm{Na}^{+}$current at $-30 \mathrm{mV}$ and was also present during a partial repolarization to $+30 \mathrm{mV}$ after more depolarized pulses $(>0$ $\mathrm{mV} ; n=5$; data not shown). The fraction of the persistent current increased during development from $6.5 \pm 0.8 \%$ of the peak current $(\mathrm{P} 7-\mathrm{P} 8)$ to $12.8 \pm 1.9 \%(\mathrm{P} 9-\mathrm{P} 12 ; p<0.01 ; n=5)$. A similar developmental increase in a slowly inactivating $\mathrm{Na}^{+}$current component has also been seen in neocortical neurons (Huguenard et al., 1988).

Studies in cultured hippocampal neurons also revealed two components of recovery from inactivation $\left(\tau_{\text {fast }}\right.$ of $3.9 \mathrm{~ms}$ and $\tau_{\text {slow }}$ of $\left.938 \mathrm{~ms}\right)$ in whole-cell soma recordings of $\mathrm{Na}^{+}$currents and nucleated patches $\left[\tau_{\text {fast }}\right.$ of $7.7 \mathrm{~ms}$ and $\tau_{\text {slow }}$ of $923 \mathrm{~ms}$ (He et al., 2002)]. The $\mathrm{Na}^{+}$current recovery from inactivation was thus somewhat slower in nucleated patches, and this suggests that the fast recovery from inactivation may be subject to some corrections for voltage- and space-clamp escape. We attempted nucleated patches but had no success, probably because of the large size of the MNTB principal cell nucleus. However, after whole-cell recording of $\mathrm{Na}^{+}$currents, we did obtain outside-out patches from the principal cells. These patches contained small $\mathrm{Ca}^{2+}$ and $\mathrm{K}^{+}$currents, but, after blocking these with $200 \mu \mathrm{M} \mathrm{Cd}^{2+}$ and 10 mM TEA, no $\mathrm{Na}^{+}$currents were observed ( $n=5$ patches), indicating an absence, or very low density, of $\mathrm{Na}^{+}$channels in the principal cell soma. This agrees with the lack of strong immuno- 
A
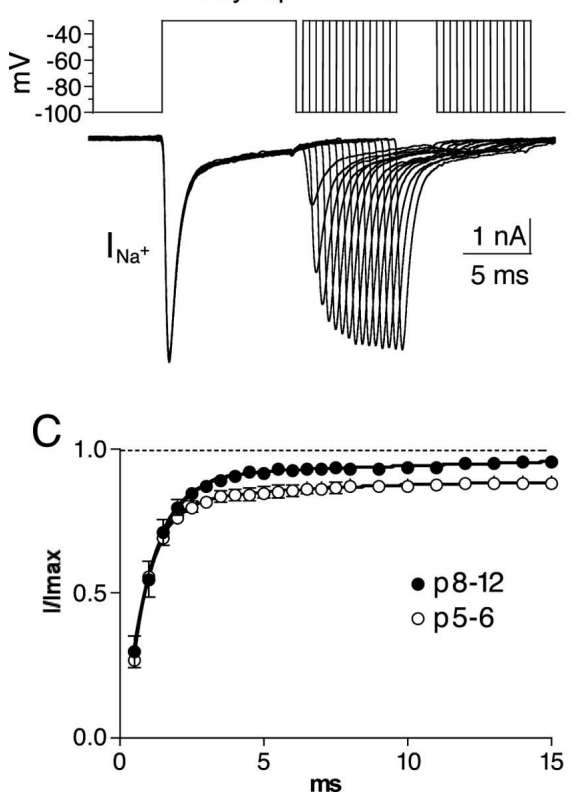

B

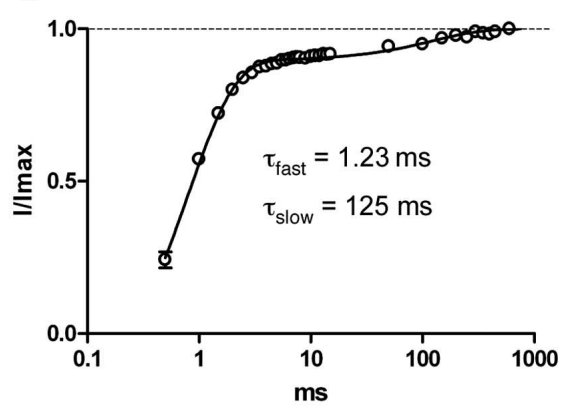

D

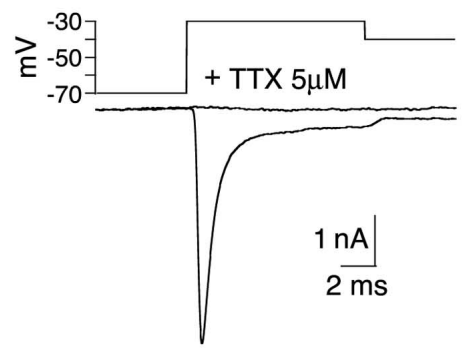

Figure 5. Recovery from inactivation of postsynaptic $\mathrm{Na}^{+}$currents. $\boldsymbol{A}$, Pairs of $\mathrm{Na}^{+}$currents elicited by step depolarizations and separated by different time intervals from 0.5 to $7.5 \mathrm{~ms}$. Note the non-inactivating current. $\boldsymbol{B}$, Complete recovery from inactivation of the postsynaptic $\mathrm{Na}^{+}$current after $500 \mathrm{~ms}$. Plot of the fraction of the $\mathrm{Na}^{+}$current recovered after various time intervals (1-600 ms). The line is a double-exponential fit to the points ( $n=5$ cells for P7-P10 rats). C, Developmental difference in the fraction of slow-recovering $\mathrm{Na}^{+}$current between cells from $\mathrm{P} 5-\mathrm{P} 6$ and $\mathrm{P} 8-\mathrm{P} 12$ rats. The fraction recovered at $15 \mathrm{~ms}$ was $88 \pm 1.7 \%$ in P5-P6 $(n=5)$ and $96 \pm 1.4 \%$ in P8 $-\mathrm{P} 12(n=6 ; p<0.05)$. $\boldsymbol{D}$, An example of a TTX-sensitive $\mathrm{Na}^{+}$current recorded from a principal cell that shows a fast-inactivating component and a persistent current.

labeling for PAN-NaCh (PAN-Na ${ }^{+}$channels) in the postsynaptic principal cell (see Figs. $7 B, 9$ ). We suggest that postsynaptic $\mathrm{Na}^{+}$channels may be highly clustered near the axon hillock (or farther down the axon initial segment), which was probably missed by our outside-out patches (Colbert and Pan, 2002).

To determine the recovery from inactivation with better voltage-clamp control, we acutely dissociated the principal cells. Figure $6 \mathrm{~A}$ shows a typical DIC image of a $\mathrm{P} 9$ principal cell from the MNTB with a diameter of $\sim 20-25 \mu \mathrm{m}$ and one short dendrite (Sätzler et al., 2002). In current-clamp mode, these neurons fired one AP for small- and large-current amplitude injections $(n=5)$ (Fig. $6 B)$. This is characteristic of MNTB principal cells (Banks and Smith, 1992; Forsythe, 1994). Depolarization to -30 $\mathrm{mV}$ induced a transient $\mathrm{Na}^{+}$current with average amplitude of $5.67 \pm 1.80 \mathrm{nA}(n=11)$, which was completely blocked by $5 \mu \mathrm{M}$ TTX $(n=2)$ (Fig. 6C). A typical $I-V$ curve of $\mathrm{Na}^{+}$current is displayed in Figure $6 D$, showing that the voltage control was good for these dissociated cells. Here the liquid junction potential was measured as $15.6 \mathrm{mV}$ and corrected after the recording. An example of $\mathrm{Na}^{+}$currents elicited by paired depolarizations to $-30 \mathrm{mV}$ with different time intervals $(0.5-7.5 \mathrm{~ms})$ is shown in Figure $6 E$. Using this paired-pulse protocol with dissociated neurons (step depolarizing pulses to -30 or $0 \mathrm{mV}$ ), we obtained the recovery from inactivation (Fig. $6 F$ ). Again, as in slice recordings, a double exponential was necessary to fit the data with $\tau_{\text {fast }}$ of $1.5-1.7 \mathrm{~ms}$ and $\tau_{\text {slow }}$ of $80-86 \mathrm{~ms}$. Thus, pulses to -30 or $0 \mathrm{mV}$ give similar values for $\tau_{\text {fast }}$ and $\tau_{\text {slow }}$, and these values are also quite similar to the slice recordings ( $\tau_{\text {fast }}$ of 1.23 and $\tau_{\text {slow }}$ of 125), suggesting that the time constant of recovery from inactivation may not be so sensitive a parameter to less than ideal voltage- and space-clamp control.

\section{$\mathrm{Na}^{+}$channel locus}

As described above, most presynaptic outside-out patches did not express $\mathrm{Na}^{+}$ currents. This suggested that $\mathrm{Na}^{+}$channels may be highly clustered on the calyx or there may be a steep gradient in $\mathrm{Na}^{+}$ channel expression with a higher density on the axonal heminode compared with the calyx membrane. We determined the locus of $\mathrm{Na}^{+}$channels by double labeling the MNTB with antibodies against the $\mathrm{Na}^{+}$channel $\alpha$-subunit and the synaptic vesicle protein SV2 (Fig. 7). We first used an antibody that recognizes all known voltage-gated $\mathrm{Na}$ channel $\alpha$-subunits (PAN-NaCh) (Dugandzija-Novakovic et al., 1995). Immunocytochemistry with the PAN-NaCh antibody revealed a dense labeling in MNTB neuronal processes (Fig. $7 B$ ) that was abolished by preabsorption of the antibody with the antigenic peptide. Conversely, immunolabeling for SV2 revealed continuous structures surrounding the principal cells (Fig. 7C) (Wu et al., 1999). No overlap was observed when the PAN-NaCh and SV2 staining were merged (Fig. 7D, example arrowhead shows an axon segment, and the arrow shows a putative calyx). Calyceal axons of the MNTB often have a characteristic bend before they form the calyx, as shown in Figure $7 \mathrm{~A}$ (Lucifer yellow-stained calyx and axon) (Kubawara et al., 1991). This characteristic bend or twist of calyceal axon was sometimes observed with the $\mathrm{Na}^{+}$channel labeling (Fig. $7 F$, asterisk), and, in some confocal sections, the membrane of the thick calyceal axon could be clearly delineated in a longitudinal cross section (Fig. 7F, arrow). PAN-NaCh staining was concentrated in axonal processes that could often be traced back through confocal sections to a calyx or principal cell (Fig. $7 E, F$ ).

We observed intense SV2 staining around principal cells (Fig. $8 A$ ) and long bar-like structures with strong Na channel labeling in the MNTB (Fig. $8 B$ ), as can be seen also in Figure $7 B$. These bar-like structures were not found in the fibers passing through the trapezoid body. These axon-like structures were 20-40 $\mu \mathrm{m}$ long when traced through successive confocal sections, and they suggested an unusually long nonmyelinated heminodal region before the formation of the calyx nerve terminal. We suggest that our $\sim 30 \%$ outside-out patches with Na currents probably come from patches containing membrane from this heminode region rich in $\mathrm{Na}$ channel protein.

\section{$\mathrm{Na}_{\mathrm{v}} 1.6$ (but not $\mathrm{Na}_{\mathrm{v}} 1.2$ ) is present in the MNTB}

We observed a developmental change in the inactivation kinetics of the $\mathrm{Na}$ currents (Fig. $3 B$ ). It is possible that $\mathrm{Na}$ channel $\alpha$-subunit composition changes during development in the MNTB, and this could account for these functional changes. Among the different $\alpha$-subunits present in the $\mathrm{CNS}, \mathrm{Na}_{\mathrm{v}} 1.2$ and $\mathrm{Na}_{\mathrm{v}} 1.6$ are abundantly expressed in axons and nodes of Ranvier (Westenbroek et al., 1989; Caldwell et al., 2000; Krzemien et al., 2000), and a developmental switch from $\mathrm{Na}_{\mathrm{v}} 1.2$ to $\mathrm{Na}_{\mathrm{v}} 1.6$ has been described by Boiko et al. (2001) and Kaplan et al. (2001). These authors suggested that nerve myelination induces the clustering of Na channels in the nodes of Ranvier. Myelination of the 
rat brainstem starts after approximately P7, and a developmental switch from one $\alpha$-subunit to another could be responsible for some of our developmental changes in the Na current properties (Fig. 3). To address this question, we investigated the distribution of $\mathrm{Na}_{\mathrm{v}} 1.2$ and $\mathrm{Na}_{\mathrm{v}} 1.6$ subunits in the MNTB of rats in different age groups.

Figure $8 C-F$ depicts the immunoreactivity profiles generated with specific antibodies directed against both $\alpha$-subunits at two distinct developmental stages (P6 and P13). We found no substantial $\mathrm{Na}_{\mathrm{v}} 1.2 \mathrm{im}$ munolabeling of the MNTB in either age group (Fig. $8 D, F$ ) despite the fact that other brainstem structures, such as the pyramids, displayed marked immunoreactivity levels (data not shown). These labeled structures thus served as internal positive controls of our immunocytochemical procedure. Similar results were also observed with immunofluorescence with anti- $\mathrm{Na}_{\mathrm{v}} 1.2$ (data not shown). Thus, unlike other PNS and CNS areas, the nearubiquitous $\mathrm{Na}_{\mathrm{v}} 1.2 \alpha$-subunits do not seem to be expressed in the MNTB.

Immunocytochemistry directed at $\mathrm{Na}_{\mathrm{v}} 1.6$ revealed a marked increase in expression levels with age. We found that, although some $\mathrm{Na}_{\mathrm{v}} 1.6$ immunoreactivity could be detected at P6, a substantial increase in immunolabeling occurred between this age and P13 (Fig. 8C,E). When immunofluorescence was used, structures similar to those observed with the PAN antibody were seen with the anti- $\mathrm{Na}_{\mathrm{v}} 1.6$ in MNTB from P13 and P10 rats (Fig. 8G). However, no significant immunofluorescence labeling was observed in P7 rats. $\mathrm{Na}_{\mathrm{v}} 1.6$ labeling was also less intense than labeling observed with the nonselective PAN-NaCh antibody. Based on these results, we suggest that an increase in $\mathrm{Na}_{\mathrm{v}} 1.6$ subunit expression occurs during development in the MNTB, perhaps replacing other slower gating isoforms. This increase in expression could account, at least in part, for the developmental changes observed with our electrophysiological experiments [e.g., the increase in upstroke speed of the calyx AP with increasing age (Taschenberger and von Gersdorff, 2000)]. Interestingly, recent electrophysiological data comparing the properties of $\mathrm{Na}_{\mathrm{v}} 1.2$ and $\mathrm{Na}_{\mathrm{v}} 1.6$ shows that $\mathrm{Na}_{\mathrm{v}} 1.6$ has a faster activation kinetics and is more resistant to cumulative inactivation during stimulus trains, indicating that $\mathrm{Na}_{\mathrm{v}} 1.6$ is better suited for high-frequency firing than $\mathrm{Na}_{\mathrm{v}} 1.2$ (Zhou and Goldin, 2004).

Although we cannot completely exclude the possibility that some of the 20- to $40-\mu \mathrm{m}$-long, bar-like structures seen with PAN-NaCh and $\mathrm{Na}_{\mathrm{v}} 1.6$ immunolabeling may represent axons leaving the postsynaptic principal cell, several lines of anatomical evidence support the conclusion that they are pre-calyx axonal the averaged data.
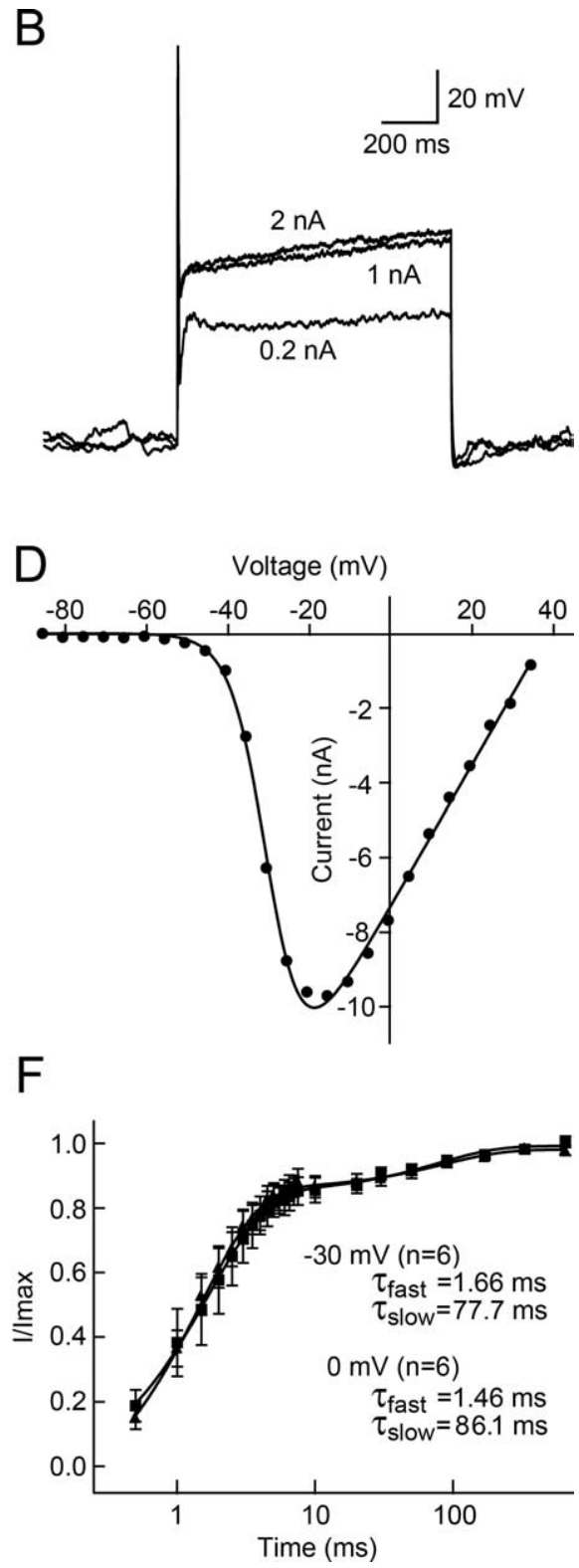

Figure 6. Recovery from inactivation of postsynaptic $\mathrm{Na}^{+}$currents: acutely dissociated principal cells. $\boldsymbol{A}$, DIC image of a representative isolated principal neuron from the MNTB. Note the short dendrites. Scale bar, $20 \mu \mathrm{m}$. $\boldsymbol{B}$, In current-clamp mode, these neurons fired APs only once no matter how much constant current was injected. Three different current injection amplitudes are shown (each produced only $1 \mathrm{AP}) . \mathrm{C}$, When both $\mathrm{Ca}^{2+}$ and $\mathrm{K}^{+}$current was blocked, depolarization to $-30 \mathrm{mV}$ induced a transient $\mathrm{Na}^{+}$current that was completely blocked by $5 \mu \mathrm{m}$ TTX. Same cell as shown in $\boldsymbol{A}$. D, I-V curve of the Na ${ }^{+}$current. $\boldsymbol{E}$, Paired depolarizations to $-30 \mathrm{mV}$ with different time intervals $(0.5-7.5 \mathrm{~ms})$ were delivered to elicit sodium current. $\boldsymbol{F}$, The same pulse protocol as in $\boldsymbol{E}$ was applied to neurons [depolarized to $-30 \mathrm{mV}(\square)$ or $0 \mathrm{mV}(\boldsymbol{\Delta})$ ], and the peak sodium current induced by the second depolarization was normalized to that induced by the first one; then the normalized data were averaged among different neurons ( $n=6$ for both cases) and plotted against the depolarization intervals. Solid lines are double-exponential fits to

heminodes. First, the calyceal axons are the largest fibers in the trapezoid body, having 4-15 $\mu \mathrm{m}$ diameters depending on species (Spirou et al., 1990; Kubawara et al., 1991), whereas the principal cell axons have a thinner diameter of $2-8 \mu \mathrm{m}$ near the principal cell body (Kubawara and Zook, 1991; Smith et al., 1998b). The calyceal axons are thus much thicker than the principal cell axons. Our electron microscopy also indicates that the principal cell axon is relatively thin for P14 rats (1.0-1.5 $\mu$ m diameter; see below). A curved pathway in the MNTB with an abrupt bend before forming the calyx is a characteristic of the calyceal axon (Kubawara et al., 1991) (Fig. 

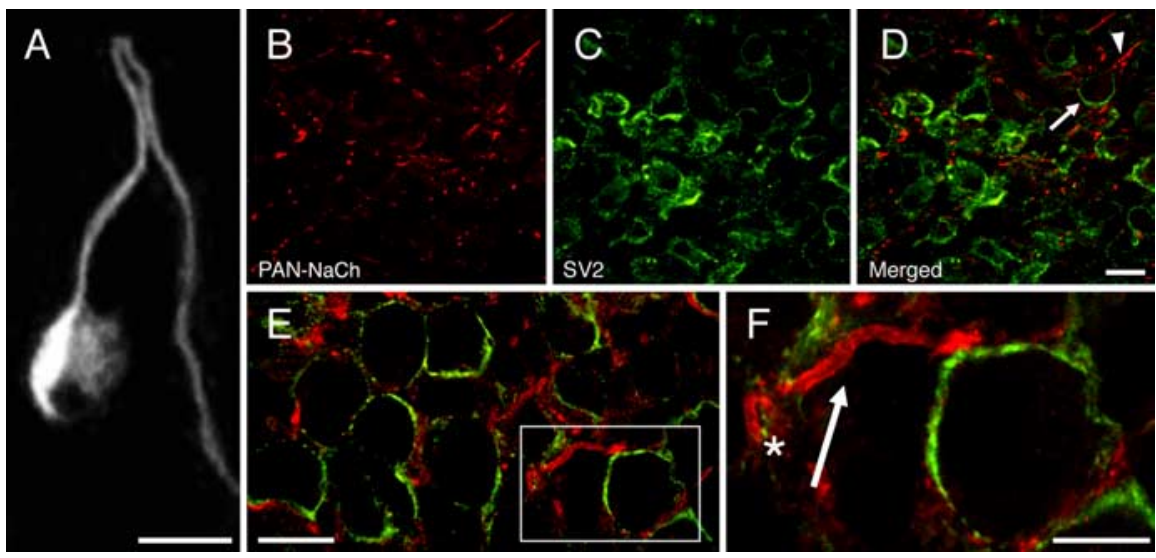

Figure 7. $\mathrm{Na}^{+}$channels are excluded from the calyx. $A$, Lucifer yellow staining of the calyx of Held and axon from a P8 rat. The calyx was filled with dye via a patch-pipette recording. $\boldsymbol{B}-\boldsymbol{F}$, Confocal sections of MNTB slices labeled with anti-Na PAN antibody (red) and anti-SV2 antibody (green). $\boldsymbol{B}$, $\boldsymbol{C}$, Single excitation of the anti-Na channel-PAN-Alexa 488 conjugate ( $\boldsymbol{B}$; PAN-NaCh) and anti-SV2-Alexa 568 conjugate (C). D, Merging of the images in $\boldsymbol{B}$ and $\boldsymbol{C}$ showing the lack of overlap of Na channels and SV2 proteins. The arrow shows a calyceal terminal, revealed by the SV2 labeling, that appears connected to an axon-like structure formed by the Na channel labeling (arrowhead). Slice from a P7 rat. $E$, Example of another confocal plane from a different slice, in which many calyces can be seen (green) not overlapping with $\mathrm{Na}^{+}$channels (red). An axon-like structure can be seen in the image inside the square. Slice from a P10 rat. $F$, Magnification of the area in the square in $\boldsymbol{E}$, in which the labeling of the axonal membrane by the anti Na-PAN antibody (red) can be clearly seen. The thick axon (arrow) can be traced through successive confocal sections. To the right, it ends adjacent to a calyx-like terminal (green). Following the axon staining away from the terminal reveals that it abruptly ends inside the middle of the slice, perhaps attributable to myelination. The asterisk makes a sharp bend in the axon, a characteristic of the calyceal axons as can be seen in the Lucifer yellow-filled axon in $\boldsymbol{A}$. Scale bars: $\boldsymbol{A}-\boldsymbol{E}, 20 \mu \mathrm{m} ; \boldsymbol{F}, 10 \mu \mathrm{m}$.
SV2
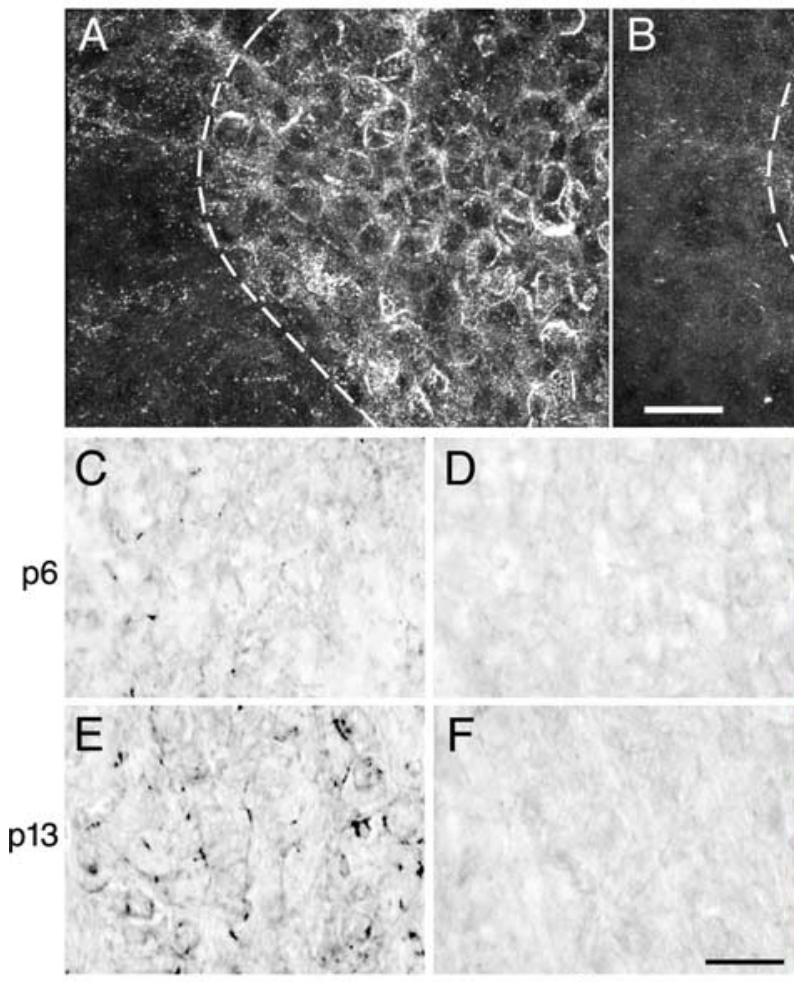

$\mathrm{Na}_{\mathrm{v}} 1.6$

$\mathrm{Na}_{\mathrm{v}} 1.2$

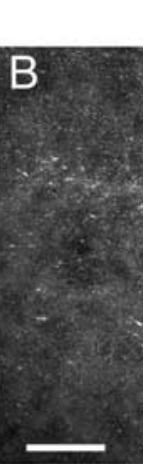

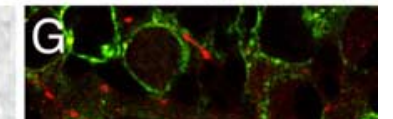

PAN-NaCh
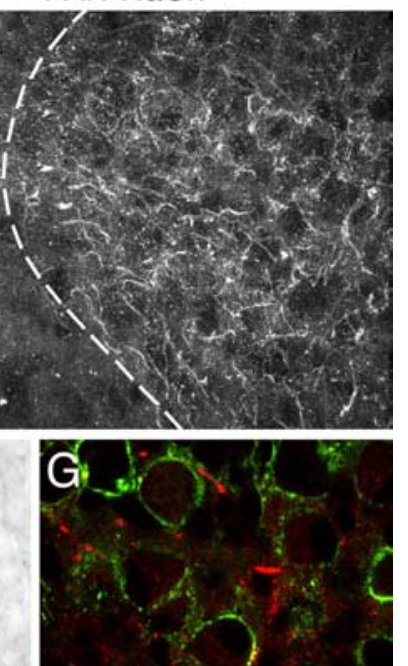

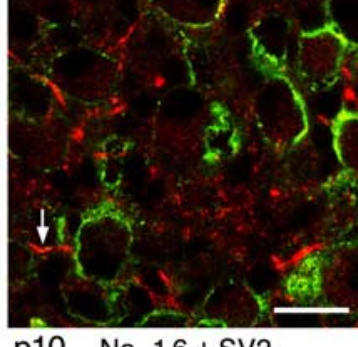

p10 $\mathrm{Na}_{\mathrm{v}} 1.6+\mathrm{SV} 2$

Figure 8. Confocal reconstruction of the calyceal $(\boldsymbol{A})$ and axonal $(\boldsymbol{B})$ structures in the MNTB. The dashed line represents the boundary of the MNTB. Image from a P7 rat. Scale bar, (in $\boldsymbol{B}) 40 \mu \mathrm{m}$. $\boldsymbol{C}-\boldsymbol{F}$, Immunolabeling of the MNTB for $\mathrm{Na}_{\mathrm{v}} 1.6$ subunit $(\boldsymbol{C}, \boldsymbol{E})$ but not for the $\mathrm{Na}_{v} 1.2$ subunit $(\boldsymbol{D}, \boldsymbol{F})$. Expression of $\mathrm{Na}_{v} 1.6$ is especially clear in the P13 slice. $\boldsymbol{G}$, Immunofluorescence for $\mathrm{Na}_{v} 1.6$ and SV2. A confocal plane through the MNTB from a P10 rat labeled for SV2 (green) and $\mathrm{Na}_{\mathrm{v}} 1.6$ (red). The white arrowhead indicates a putative heminode that ends to the right on a putative calyx. Scale bars: $\mathbf{C}-\boldsymbol{F}, 40 \mu \mathrm{m} ; \boldsymbol{G}, 20 \mu \mathrm{m}$.

$7 A)$. In contrast, the principal cell axons tend to curve one time inside the MNTB and follow a relatively straight pathway toward the lateral superior olivary nucleus (Kubawara and Zook, 1991). The structures shown in Figure $7 F$, labeled by the PAN-NaCh and $\mathrm{Na}_{\mathrm{v}} 1.6$ antibodies, match these descriptions of the calyceal axon. They are not seen outside the MNTB (Fig. $8 B$ ). In addition, these structures were often closely associated with a putative calyx terminal (Figs. $7 D, F, 8 G$ ). Furthermore, a series of immunofluorescent confocal images with PAN-NaCh staining of a rat brainstem slice (P13) shows that the bar-like structures (Fig. 9A) are present completely inside the slice at an age when myelination is already significant (Fig. 9B$D$ ). This indicates that the bar-like structures are not attributable to the cutting of axons by the slicing procedure, which often leaves long stretches of axon intact (Fig. 7A). We thus conclude that they probably reflect the axonal heminode region of the calyx.

\section{Electron microscopy of}

calyceal heminodes

To confirm that there are extended lengths of unmyelinated axon preceding the calyx of Held terminal, we performed serial EM reconstructions of ultrathin and semithin sections from P14 animals. Fortuitous sections revealed long unmyelinated axonal segments leading into the calyx (Fig. 10A). Because of bending of the calyceal axon (Fig. $7 A)$ (see Discussion), we were able to trace axons to the their set of paranodal loops in only three cases, yielding heminode lengths of 12,32 , and $36 \mu \mathrm{m}$ (latter axon shown in Fig. $10 B-D$ ). An additional nine axons were traced for $>10 \mu \mathrm{m}$ from the calyx terminal without reaching the onset of myelination $(12,13,17,19,21,21,22,29$, and $46 \mu \mathrm{m})$ before extending outside of our range of sections. A three-dimensional reconstruction of a completely traced axon (Fig. $10 B-D$ ) reveals its bending trajectory en route to its target calyx synapse (Fig. 10E). The average diameter of these axons was $2.16 \pm 0.46 \mu \mathrm{m}$ (mean $\pm \mathrm{SD} ; n=12$ ). In one case, we were able to trace an MNTB principal cell axon from the cell body to the initial set of paranodal loops, covering a distance of $20 \mu \mathrm{m}$; the axonal diameter varied from 1.0 to $1.5 \mu \mathrm{m}$. These axonal diameters are in good agreement with previous DiI and Lucifer yellow confocal fluorescence images, which also show that the calyceal axon is clearly thicker than the principal cell axon (Forsythe, 1994). Finally, note the large density of mitochondria throughout the heminode region of the axon, which probably provides the $\mathrm{Na}^{+} / \mathrm{K}^{+}$ pumps on the heminode with a ready supply of ATP during high-frequency firing. 

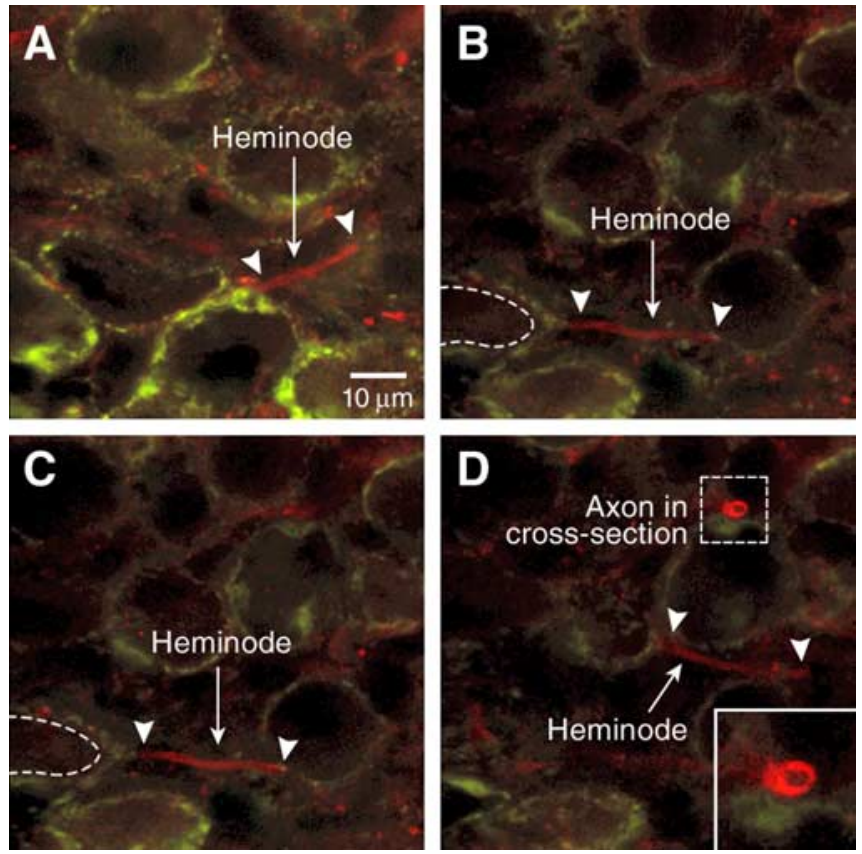

Figure 9. Sequence of confocal images from a P13 MNTB slice labeled with anti-Na PAN antibody (red) and anti-SV2 antibody (green). In $A$, an image near the top of the slice shows a heminode marked by two arrowheads. $\boldsymbol{B}-\boldsymbol{D}$ are confocal sections obtained after focusing continuously downward into the same slice. $\boldsymbol{B}$ shows another bar-like heminode structure that ends on a calyx-like structure at one end (left arrowhead; the dashed line outlines the principal (ell), and, on the other end, the staining ends abruptly (right arrowhead; presumably because of myelin). ( shows that the same bar-like structure of $\boldsymbol{B}$ is still visible after focusing a bit farther down into the slice, but this bar-like structure disappears completely after focusing just a bit farther down (data not shown). D shows another putative heminode axon (between the arrowheads) and a fortuitous image of a heminode axon in cross section (dashed square; the inset shows the same square region blown up 2 -fold).

\section{Modeling the calyx AP at different Na channel densities}

The immunocytochemical experiments demonstrate an absence of $\mathrm{Na}^{+}$channels at the calyx of Held terminal. To examine the functional consequences of such asymmetric distribution of $\mathrm{Na}$ channels in the calyx terminal, we performed a modeling study using the program NEURON (Hines and Carnavale, 2001). A previously recorded calyx of Held action potential waveform was used to voltage clamp the axon close to the calyx, and the resulting induced potential was recorded in the calyceal stalks and swellings (for details, see Materials and Methods). Figure $8 \mathrm{~F}$ shows that the calculated AP with shortest half-width occurred when the $\mathrm{Na}^{+}$conductance was set to zero in the calyx. Increasing the $\mathrm{Na}$ conductance led to successive broadening of the calyx AP waveform (Fig. 10F) [similar AP simulations were performed for lizard neuromuscular junction (NMJ) motor nerve terminals, which also have a very low density of $\mathrm{Na}^{+}$channels, and they give the same result (Lindgren and Moore, 1989)]. The AP half-width in the calyx calculated from the swelling indicated in Figure $10 \mathrm{~F}$ significantly increased from 0.278 to $0.333 \mathrm{~ms}$ when the $\mathrm{Na}^{+}$ conductance changed from 0 to $0.25 \mathrm{~S} / \mathrm{cm}^{2}$ on the calyx, whereas the AP overshoot changed from 38 to $49 \mathrm{mV}$ (the original AP in the axon had a half-width of $0.254 \mathrm{~ms}$ and overshoot of $45.7 \mathrm{mV}$ and was recorded from a P12 rat). Consequently, it seems that restricting $\mathrm{Na}^{+}$channels to the heminode still ensures a fast and potent depolarization that can spread uniformly to the calyx without the necessity of distal Na channels on the calyceal fingers.

Note that the passive attenuation in height of the presynaptic $\mathrm{AP}$ as it propagates through the calyx structure to reach a distal tip is relatively small (change in overshoot from 45.7 to $38 \mathrm{mV}$ ) (Fig. 10 F). Placing Na channels in the terminal boosts the height of the original AP from 45.7 to $49 \mathrm{mV}$. Such a small increase in AP height may, however, have a significant effect on release probability (Wu et al., 2004). Interestingly, outside-out patches from mossy fiber nerve terminals express a relatively high density of $\mathrm{Na}$ channels, and biophysical simulations show that presynaptic $\mathrm{Na}$ channels boost the height of the AP (and thus release probability) at these en passant beads-on-string boutons (Engel and Jonas, 2004).

It is also noteworthy that internode distances along a myelinated nerve often become progressively shorter as one approaches the preterminal region, in which they can be as short as $30 \mu \mathrm{m}$ (Waxman, 1975; Quick et al., 1979). This may avoid impedance mismatch by allowing more nodes to contribute depolarizing current to a large branched nerve terminal. This design feature of myelinated axons is thought to thus facilitate failsafe AP invasion from the myelinated truck axon to a large nonmyelinated terminal. By the same logic, the extensive calyceal membrane presents the invading AP with a large capacitor that must be quickly charged. One solution is to reduce the pre-calyx axonal internode distance to zero or, in other words, remove myelin from an extended heminode region in which $\mathrm{Na}^{+}$channels can be concentrated to provide the fast and large $\mathrm{Na}^{+}$current needed to quickly charge the calyceal capacitor, thus generating a fast AP.

\section{Discussion}

$\mathrm{Na}^{+}$currents have been recorded from neuronal somas, dendrites, and axons, but the properties of presynaptic $\mathrm{Na}^{+}$channels are less well known (Trimmer and Rhodes, 2004). At the neuromuscular junction, controversy exists as to whether $\mathrm{Na}^{+}$channels are expressed on the nerve terminal (Brigant and Mallart, 1982). For example, lizard NMJ nerve terminals contain very little, if any, $\mathrm{Na}^{+}$current (Lindgren and Moore, 1989). However, a small TTX-sensitive extracellular current was observed in mouse motor terminals (Konishi, 1985). In the CNS cell-attached recordings from pinceau-type nerve terminals of cerebellum revealed a high density of $\mathrm{Na}^{+}$current $\left(38 \mathrm{pA} / \mu \mathrm{m}^{2}\right)$ (Southan and Robertson, 1998) and $\mathrm{Na}^{+}$current is also present in mossy fiber boutons (Engel and Jonas, 2004), whereas cell-attached recordings from single neocortical synaptosomes revealed no $\mathrm{Na}^{+}$current (Smith et al., 2004). Here we have shown that presynaptic $\mathrm{Na}^{+}$current inactivation and recovery from inactivation becomes faster as the calyx of Held matures. $\mathrm{Na}^{+}$channels were not detected in the calyx but were highly concentrated in the axonal heminode. What are the functional implications of these findings?

\section{Presynaptic $\mathrm{Na}^{+}$currents: fast recovery from inactivation}

Fast inactivation of $\mathrm{Na}^{+}$channels ensures that APs are brief, but this also creates a refractory period during which neurons cannot fire APs. The duration of this refractory period depends on the time necessary for the inactivated $\mathrm{Na}^{+}$channels to move back to the resting state after the repolarization of the membrane (Kuo and Bean, 1994). Thus, neurons with $\mathrm{Na}^{+}$channels that recover rapidly from inactivation are able to fire at higher frequencies (Torkkeli and French, 2002). We found time constants for the recovery from inactivation of $\sim 0.5 \mathrm{~ms}$ at $-100 \mathrm{mV}\left(35^{\circ} \mathrm{C}\right)$. $\mathrm{Al}-$ though similar time constants for recovery from inactivation have been reported for the Na current of the squid giant axon $(0.6$ $\mathrm{ms}$ at $-130 \mathrm{mV}$ ) (Bezanilla and Armstrong, 1977) and also for a TTX-resistant $\mathrm{Na}^{+}$current in dorsal root ganglion C-type neurons [ $1 \mathrm{~ms}$ at $-100 \mathrm{mV}$ (Cummins and Waxman, 1997)], the 

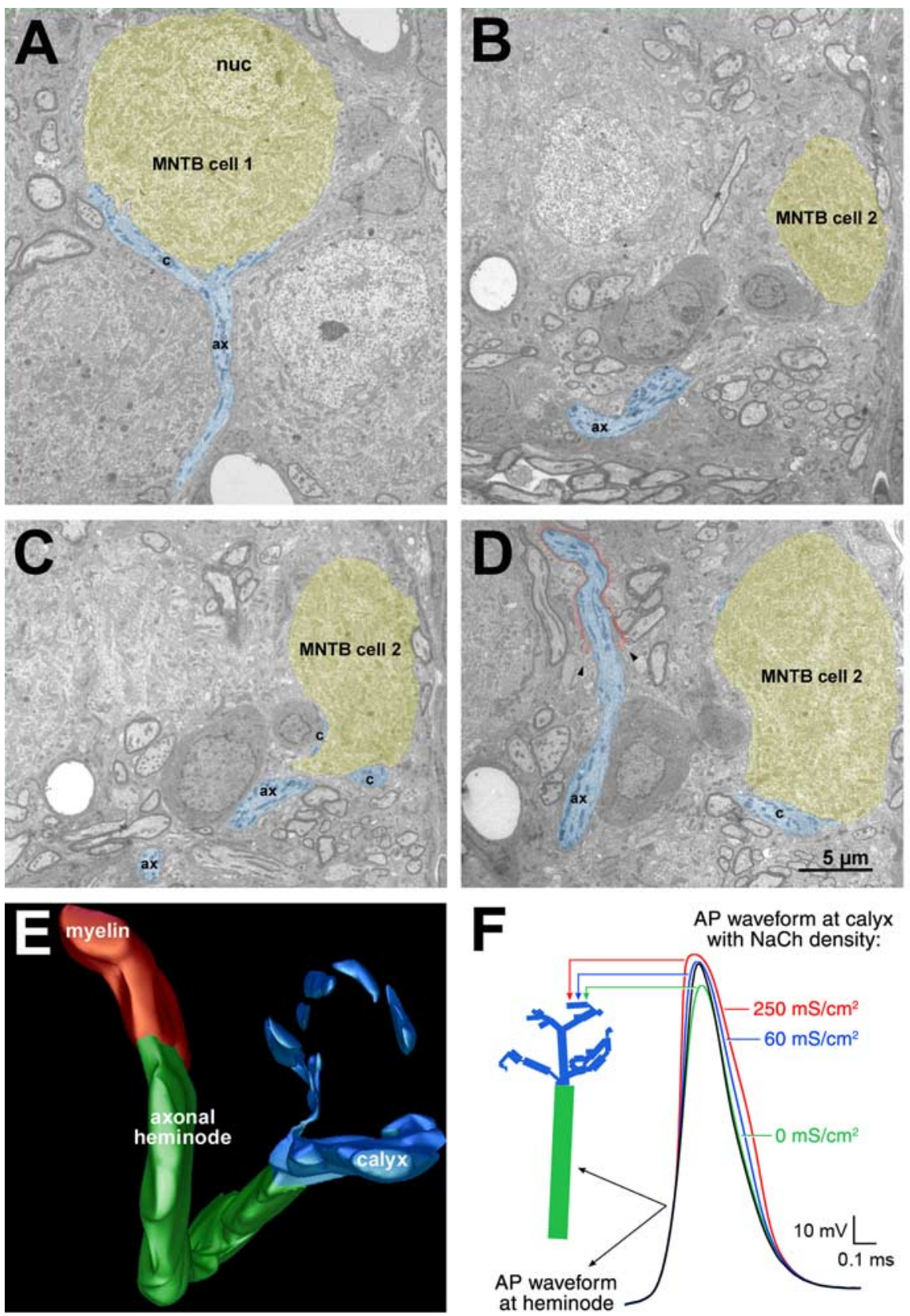

Figure 10. EM reconstruction of the axonal heminode and biophysical modeling of APs. A, A single ultrathin section captures a portion of the calyx (c) as it envelops the MNTB cell (cell 1 ) and an attached unmyelinated length of its axon (ax). The MNTB cell had a large nucleus (nuc). The axon trajectory was traced for $17 \mu \mathrm{m}$ without reaching a myelinated segment. $\boldsymbol{B}-\mathbf{D}$, Ultrathin sections tracing another axon from its emergence (arrowheads in $\boldsymbol{D}$ ) from myelin (traced in red) to termination as a calyx onto another MNTB cell (cell 2). $\boldsymbol{E}$, Threedimensional reconstruction of axon and calyceal segments contained in the series of sections exemplified by $\boldsymbol{B}-\boldsymbol{D}$. The long unmyelinated calyceal axon that gives rise to the calyx terminal is called the axonal heminode (green). $\boldsymbol{F}$, A biophysical model of APs in the calyx of Held. At left is a realistic morphology of the calyceal fingers geometrically modeled as a set of equivalent connected cylinders (see Materials and Methods; taken from a reconstruction of an adult cat calyx). Atright is an experimentally recorded P12 rat calyx AP waveform shown by the black trace. The colored AP waveforms show the AP calculated in the indicated distal swelling after it has propagated through the model calyx with different $\mathrm{Na}^{+}$conductances: 0 (green), $0.06 \mathrm{~S} / \mathrm{cm}^{2}$ (blue), and $0.25 \mathrm{~S} / \mathrm{cm}^{2}$ (red). The calyx AP has a faster upstroke, slightly larger amplitude, and a broader half-width with the larger $\mathrm{Na}^{+}$conductances of 0.06 and $0.25 \mathrm{~S} / \mathrm{cm}^{2}$.

values obtained here are faster than those reported from several neuronal somata and axons. Examples include rat motor neurons [16 $\mathrm{ms}$ at $-80 \mathrm{mV}$ (Ogata and Tatebayashi, 1993)], rat hippocampal basket cells $\left[2 \mathrm{~ms}\right.$ at $-120 \mathrm{mV}\left(24^{\circ} \mathrm{C}\right)$ (Martina and Jonas, 1997)], and rat myelinated peripheral fibers $[0.9 \mathrm{~ms}$ at $-118 \mathrm{mV}\left(37^{\circ} \mathrm{C}\right)$ (Schwarz and Eikhof, 1987)].

During development, the incidence of presynaptic AP failures during high-frequency stimulation fell dramatically (Fig. $3 A$ ). The increased rate of $\mathrm{Na}$ current recovery from inactivation may provide a mechanism for this observation. We also observed that trains of calyx APs at P6 result in a small depolarizing plateau, which is absent in P13 calyx AP trains (Fig. 3A). This standing depolarization will likely slow down the recovery from inactivation of subsequent APs (Fig. 1C). A putative increase in presynaptic voltage-dependent $\mathrm{K}$ current density, and the faster inactivation rate of $\mathrm{Na}$ currents, may both play a role in eliminating this plateau depolarization and in the shortening of AP half-width during development (Taschenberger and von Gersdorff, 2000). Finally, we note that a large surplus of $\mathrm{Na}$ channels, beyond what is needed to trigger an AP and ensure that its waveform is not altered, helps neurons to fire reliably at higher frequencies (Madeja, 2000). Accordingly, we observed an increase in the expression levels of the $\mathrm{Na}_{\mathrm{v}} 1.6$ subunit with age (Fig. 8C,E) and an improved ability of calyx APs to follow higher stimulation frequencies with increasing age (Fig. $3 A$ ). An axonal heminode of $40 \mu \mathrm{m}$ in length may contain half a million $\mathrm{Na}^{+}$ channels [assuming a uniform rat node of Ranvier density of 2000 channels/ $\mu \mathrm{m}^{2}$ (Chiu, 1980)]. This large number may be necessary to ensure the fidelity of highfrequency firing.

\section{Postsynaptic $\mathrm{Na}^{+}$currents: transient and persistent components}

$\mathrm{Na}^{+}$currents recorded from the postsynaptic principal cell also recovered rapidly from inactivation, but a fraction (5-10\%) of the current recovered significantly slower. Although $\tau_{\text {fast }}$ did not change during development, the contribution of the slowly recovering fraction decreased with age. The postsynaptic $\mathrm{Na}^{+}$current also exhibits a persistent TTX-sensitive component that increased with development. A similar increase of the persistent $\mathrm{Na}^{+}$current was also observed for cortical pyramidal neurons (Alzheimer et al., 1993). This persistent current might augment small EPSPs, which might arise during synaptic depression (von Gersdorff et al., 1997), by increasing the depolarization during the interspike interval and amplifying the current flowing through glutamate receptors (Crill, 1996).

\section{$\mathrm{Na}^{+}$channel subunits in the MNTB}

The $\mathrm{Na}_{\mathrm{v}} 1.6$ subunit is present in the MNTB, and its expression increased with development. In immature MNTB, detection of $\mathrm{Na}_{\mathrm{v}} 1.6$ required sensitive enzymatically amplified DAB immunocytochemistry (Fig. 8C), whereas in older animals it could be detected using immunofluorescence. $\mathrm{Na}_{\mathrm{v}} 1.2$ is characteristic of 
unmyelinated axons and immature nodes of Ranvier (Boiko et al., 2001), but it was not detected in the immature MNTB with either technique. Recombinant $\mathrm{Na}_{\mathrm{v}} 1.6$ expressed in Xenopus oocytes with auxiliary $\beta$-subunits, or in mouse DRG neurons, has a relatively slow recovery from inactivation $[\tau$ of $3.8 \mathrm{~ms}$ at -100 $\mathrm{mV}$ (Smith et al., 1998a; Herzog et al., 2003)] compared with $\mathrm{Na}$ currents measured in the calyx of Held. If $\mathrm{Na}_{\mathrm{v}} 1.6$ is responsible for the $\mathrm{Na}$ currents in the calyx, some factor must contribute to speeding up the recovery from inactivation (Zhou and Goldin, 2004). The increased expression of $\mathrm{Na}_{\mathrm{v}} 1.6$ with age in the MNTB could also account for the increased expression of the postsynaptic persistent Na current (Raman et al., 1997; Smith et al., 1998a), although $\mathrm{Na}_{\mathrm{v}} 1.6$ expression in the calyx does not produce this current. We conclude that the $\mathrm{Na}_{\mathrm{v}} 1.6 \alpha$-subunit (together with a particular $\beta$-subunit) could be responsible for the major portion of the Na current seen in the calyx and perhaps in the postsynaptic cell as well.

\section{$\mathrm{Na}^{+}$channel locus: the heminode}

Labeling with the PAN-NaCh antibody did not detect $\mathrm{Na}^{+}$channels in the calyx. Instead, they were concentrated on the heminode. Using antibodies against the $\mathrm{Na}_{\mathrm{v}} 1.6$ subunit, Krzemien at al. (2000) also reported an absence of $\mathrm{Na}^{+}$channels in rat NMJ nerve terminals. Caldwell et al. (2000) found that, although $\mathrm{Na}_{\mathrm{v}} 1.6$ immunofluorescence was not detected in cerebral cortex terminals (identified by double labeling with anti-SV2), it could be detected by immuno-EM. These authors suggested that the intense labeling of the anti-SV2 could be masking a small immunoreactivity signal attributable to a sparse population of $\mathrm{Na}^{+}$ channels in the terminal. In our results, however, even when we captured separately the signals from the different fluorophores used to label the $\mathrm{Na}^{+}$channels and the SV2 protein (Fig. 7 B, C), we did not see any overlap of the labels, suggesting no significant colocalization of $\mathrm{Na}^{+}$channels and synaptic vesicles. In addition, outside-out patches from the terminal often did not contain any $\mathrm{Na}^{+}$current, although $\mathrm{K}^{+}$currents could always be detected when potassium was present in the pipette solution. We conclude that $\mathrm{Na}^{+}$channels in the calyx of Held are strongly concentrated in the heminode, and they steeply drop in density at the calyceal terminal.

\section{Functional advantages to presynaptic $\mathrm{Na}^{+}$ channel segregation}

What is the physiological importance of excluding $\mathrm{Na}^{+}$channels from the calyx of Held terminal? Besides making the AP waveform briefer by avoiding a longer depolarization of the terminal attributable to the opening of distal $\mathrm{Na}^{+}$channels after the arrival of the passive depolarization from the heminode (Fig. $10 \mathrm{~F}$ ), an absence of $\mathrm{Na}^{+}$channels in the terminal avoids a potentially massive presynaptic $\mathrm{Na}^{+}$ion influx during prolonged highfrequency firing. Indeed, an estimate of sodium influx into the terminal indicates that it can be significant. A P9 calyx of Held AP (Borst and Sakmann, 1999) has a half-width of $0.5 \mathrm{~ms}$ and an overshoot of $+40 \mathrm{mV}$, parameters that are very similar to the AP of the squid giant axon, in which $\mathrm{Na}$ ion influx is $4 \mathrm{pmol} / \mathrm{cm}^{2}$ per impulse (Keynes and Lewis, 1951). A P9 calyx has a surface area of $2500 \mu \mathrm{m}^{2}$ and volume of $0.48 \mathrm{pl}$ (Sätzler et al., 2002). Thus, a calyx with a modest $\mathrm{Na}$ channel density equivalent to the squid giant axon $\left[0.06 \mathrm{~S} / \mathrm{cm}^{2}\right.$ or 300 channels $/ \mu \mathrm{m}^{2}$ (Rosenthal and Bezanilla, 2002)] produces a single AP that elevates $\left[\mathrm{Na}^{+}\right]_{\mathrm{i}}$ by 0.2 mM. Fifty APs at $500 \mathrm{~Hz}$ would raise $\left[\mathrm{Na}^{+}\right]_{\mathrm{i}}$ by $10 \mathrm{~mm}$ in $100 \mathrm{~ms}$. This transient accumulation of intraterminal $\mathrm{Na}^{+}$could disturb neurotransmission because a reduced local $\mathrm{Na}^{+}$gradient would hamper the extrusion of $\mathrm{Ca}^{2+}$ by slowing down the rate of activity of the $\mathrm{Na}^{+} / \mathrm{Ca}^{2+}$ exchanger. The $\mathrm{Na}^{+} / \mathrm{Ca}^{2+}$ exchanger, with its low affinity for $\mathrm{Ca}^{2+}$ and fast turnover rate, is particularly well suited to rapidly extrude high levels of $\mathrm{Ca}^{2+}$ at active zones ( $\mathrm{Re}-$ uter and Porzig, 1995; Regehr, 1997). Indeed, the $\mathrm{Na}^{+} / \mathrm{Ca}^{2+}$ exchanger plays a major role in extruding $\mathrm{Ca}^{2+}$ at the calyx of Held (Chuhma and Ohmori, 2002) $\left[70 \%\right.$ of $\left[\mathrm{Ca}^{2+}\right]_{\mathrm{i}}$ is extruded via $\mathrm{Na}^{+} / \mathrm{Ca}^{2+}$ exchangers (Kim et al., 2004)], and it is located on the calyx of the chick ciliary ganglion (Juhaszova et al., 2000). A reduced $\mathrm{Na}^{+}$gradient could lead to poor $\mathrm{Ca}^{2+}$ extrusion from the terminal and, consequently, to asynchronous release and a loss in temporal fidelity of synaptic transmission. Higher and more prolonged intraterminal $\left[\mathrm{Ca}^{2+}\right]_{\mathrm{i}}$ transients may also lead to an undesired facilitation of release, and thus to premature vesicle pool depletion, and thereby an inability to follow higher stimulation frequencies. Thus, $\mathrm{Na}^{+}$channel polarization may constitute an important specialization to support sustained highfrequency firing.

\section{References}

Alzheimer C, Schwindt PC, Crill WE (1993) Postnatal development of a persistent $\mathrm{Na}^{+}$current in pyramidal neurons from rat sensorimotor cortex. J Neurophysiol 69:290-292.

Banks MI, Smith PH (1992) Intracellular recordings from neurobiotinlabeled cells in brain slices of the rat medial nucleus of the trapezoid body. J Neurosci 12:2819-2837.

Barnes-Davies M, Forsythe ID (1995) Pre- and postsynaptic glutamate receptors at a giant excitatory synapse in rat auditory brainstem slices. J Physiol (Lond) 488:387-406.

Berrebi AS, Spirou GA (1998) PEP-19 immunoreactivity in the cochlear nucleus and superior olive of the cat. Neuroscience 83:535-554.

Bergsman J, De Camilli P, McCormick DA (2004) Multiple large inputs to principal cells in the mouse medial nucleus of the trapezoid body. J Neurophysiol 92:545-552.

Bezanilla F, Armstrong CM (1977) Inactivation of the sodium channel. I. Sodium current experiments. J Gen Physiol 70:549-566.

Blatchley BJ, Cooper WA, Coleman JR (1987) Development of auditory brainstem response to tone pip stimuli in the rat. Brain Res 429:75-84.

Boiko T, Rasband MN, Levinson SR, Caldwell JH, Mandel G, Trimmer JS, Matthews G (2001) Compact myelin dictates the differential targeting of two sodium channel isoforms in the same axon. Neuron 30:91-104.

Borst JGG, Sakmann B (1999) Effect of changes in action potential shape on calcium currents and transmitter release in a calyx-type synapse of the rat auditory brainstem. Philos Trans R Soc Lond B Biol Sci 354:347-355.

Borst JGG, Helmchen F, Sakmann B (1995) Pre- and postsynaptic wholecell recordings in the medial nucleus of the trapezoid body of the rat J Physiol (Lond) 489:825-840.

Brigant JN, Mallart A (1982) Presynaptic currents in mouse motor endings. J Physiol (Lond) 402:619-636.

Caldwell JH, Schaller KL, Lasher RS, Peles E, Levinson SR (2000) Sodium channel $\mathrm{Na}_{\mathrm{v}} 1.6$ is localized at nodes of Ranvier, dendrites and synapses. Proc Natl Acad Sci USA 97:5616-5620.

Cantrell AR, Catterall WA (2001) Neuromodulation of $\mathrm{Na}^{+}$channels: and unexpected form of cellular plasticity. Nat Rev Neurosci 2:397-407.

Carr CE, Soares D, Parameshwaran S, Perney T (2001) Evolution and development of time coding systems. Cur Opin Neurobiol 11:727-733.

Chiu SY (1980) Asymmetry currents in the mammalian myelinated nerve. J Physiol (Lond) 309:499-519.

Chuhma N, Ohmori H (2002) Role of $\mathrm{Ca}^{2+}$ in the synchronization of transmitter release at calyceal synapses in the auditory system of rat. J Neurophysiol 87:222-228.

Clay JR (1998) Excitability of the squid giant axon revisited. J Neurophysiol 80:903-913.

Colbert CM, Pan E (2002) Ion channel properties underlying axonal action potential initiation in pyramidal neurons. Nat Neurosci 6:533-538.

Crill WE (1996) Persistent sodium current in mammalian central neurons. Annu Rev Physiol 58:349-362.

Cummins TR, Waxman SG (1997) Downregulation of tetrodotoxinresistant sodium currents and upregulation of a rapidly repriming 
tetrodotoxin-sensitive sodium current in small spinal sensory neurons after nerve injury. J Neurosci 17:3503-3514.

Dodson PD, Billups B, Rusznak Z, Szucs G, Barker MC, Forsythe ID (2003) Presynaptic rat Kv1.2 channels suppress synaptic terminal hyperexcitability following action potential invasion. J Physiol (Lond) 550:27-33.

Dugandzija-Novakovic S, Koszowski AG, Levinson SR, Shrager P (1995) Clustering of $\mathrm{Na}$ channels and node of Ranvier formation in remyelinating axons. J Neurosci 15:492-502.

Engel D, Jonas P (2004) Presynaptic voltage-gated $\mathrm{Na}^{+}$channels boost action potentials in hippocampal mossy fiber boutons. Soc Neurosci Abstr 30:397.4.

Forsythe ID (1994) Direct patch recording from identified presynaptic terminals mediating glutamatergic EPSCs in the rat CNS, in vitro. J Physiol (Lond) 479:381-387.

Geiger JR, Jonas P (2000) Dynamic control of presynaptic $\mathrm{Ca}^{2+}$ inflow by fast-inactivating $\mathrm{K}^{+}$channels in hippocampal mossy fiber boutons. Neuron 28:927-939.

Gong B, Rhodes KJ, Bekele-Arcuri Z, Trimmer JS (1999) Type I and type II Na1 channel alpha-subunit polypeptides exhibit distinct spatial and temporal patterning, and association with auxiliary subunits in rat brain. J Comp Neurol 412:342-352.

Guinan JJ, Li RY-S (1990) Signal processing in brainstem auditory neurons which receive giant endings (calyces of Held) in the medial nucleus of the trapezoid body of the cat. Hear Res 49:321-334.

$\mathrm{He}$ Y, Zorumski CF, Mennerick S (2002) Contribution of presynaptic $\mathrm{Na}^{+}$ channel inactivation to paired-pulse synaptic depression in cultured hippocampal neurons. J Neurophysiol 87:925-936.

Herzog RI, Cummins TR, Ghassemi F, Dib-Hajj SD, Waxman SG (2003) Distinct repriming and closed-state inactivation kinetics of Nav1.6 and Nav1.7 sodium channels in mouse spinal sensory neurons. J Physiol (Lond) 551:741-750.

Hille B (2001) Ion channels of excitable membranes, Ed 3, p 46. Sunderland, MA: Sinauer.

Hille B, Woodhull AM, Shapiro BI (1975) Negative surface charge near sodium channels of nerve: divalent ions, monovalent ions, and $\mathrm{pH}$. Philos Trans R Soc Lond B Biol Sci 270:301-318.

Hines ML, Carnavale NT (2001) NEURON: a tool for neuroscientists. Neuroscientist 7:123-135.

Huguenard JR, Hamill OP, Prince DA (1988) Developmental changes in $\mathrm{Na}^{+}$conductances in rat neocortical neurons: appearance of a slowly inactivating component. J Neurophysiol 59:778-795.

Ishikawa T, Nakamura Y, Saitoh N, Li W-B, Iwasaki S, Takahashi T (2003) Distinct roles of Kv1 and Kv3 potassium channels at the calyx of Held presynaptic terminal. J Neurosci 23:10445-10453.

Jackson MB, Zhang SJ (1995) Action potential propagation and propagation block by GABA in rat posterior pituitary nerve terminals. J Physiol (Lond) 483:597-611.

Jackson MB, Konnerth A, Augustine GA (1991) Action potential broadening and frequency-dependent facilitation of calcium signals in pituitary nerve terminals. Proc Natl Acad Sci USA 88:380-384.

Johnston D, Hoffman DA, Colbert CM, Magee JC (1999) Regulation of back-propagating action potentials in hippocampal neurons. Cur Opin Neurobiol 9:288-292.

Joshi I, Wang L-Y (2002) Developmental profiles of glutamate receptors and synaptic transmission at a single synapse in the mouse auditory brainstem. J Physiol (Lond) 540:861-873.

Juhaszova M, Church P, Blaustein MP, Stanley EF (2000) Location of calcium transporters at presynaptic terminals. Eur J Neurosci 12:839-846.

Kandler K, Friauf E (1993) Pre- and postnatal development of efferent connections of the cochlear nucleus in the rat. J Comp Neurol 328:161-184.

Kanold PO, Manis PB (1999) Transient potassium currents regulate the discharge patterns of dorsal cochlear nucleus pyramidal cells. J Neurosci 19:2195-2208.

Kaplan MR, Cho M-H, Ullian EM, Isom LL, Levinson SR, Barres BA (2001) Differential control of clustering of the sodium channels $\mathrm{Na}_{\mathrm{v}} 1.2$ and $\mathrm{Na}_{\mathrm{v}} 1.6$ at developing CNS nodes of Ranvier. Neuron 30:105-119.

Keynes RD, Lewis PR (1951) The sodium and potassium content of cephalopod nerve fibers. J Physiol (Lond) 114:151-182.

Kim M-H, Korogod N, Schneggenburger R, Park KH, Ho W-K, Lee S-H (2004) Presynaptic calcium clearance mechanisms at a fast central synapse. Soc Neurosci Abstr 30:506.9.
Konishi T (1985) Electrical excitability of motor nerve terminals in the mouse. J Physiol (Lond) 366:411-421.

Krzemien DM, Schaller KL, Levinson SR, Caldwell JH (2000) Immunolocalization of sodium channel isoform $\mathrm{NaCh} 6$ in the nervous system. J Comp Neurol 420:70-83.

Kubawara N, Zook JM (1991) Classification of the principal cells of the medial nucleus of the trapezoid body. J Comp Neurol 314:707-720.

Kubawara N, DiCaprio RA, Zook JM (1991) Afferents to the medial nucleus of the trapezoid body and their collateral projections. J Comp Neurol 314:684-706.

Kuo C-C, Bean BP (1994) $\mathrm{Na}^{+}$channels must deactivate to recover from inactivation. Neuron 12:819-829.

Lindgren CA, Moore JW (1989) Identification of ionic currents at presynaptic nerve endings of the lizard. J Physiol (Lond) 414:201-222.

Madeja M (2000) Do neurons have a reserve of sodium channels for the generation of action potentials? A study on acutely isolated CA1 neurons from the guinea-pig hippocampus. Eur J Neurosci 12:1-7.

Martina M, Jonas P (1997) Functional differences in $\mathrm{Na}^{+}$channel gating between fast-spiking interneurones and principal neurones of rat hippocampus. J Physiol (Lond) 595:593-603.

Ming G, Wang L-Y (2003) Properties of voltage-gated sodium channels in developing auditory neurons of the mouse in vitro. Chin Med Sci J 18:67-74.

Ogata N, Tatebayashi H (1993) Kinetic analysis of two types of $\mathrm{Na}^{+}$channels in rat dorsal root ganglia. J Physiol (Lond) 466:9-37.

Oertel D (1999) The role of timing in the brain stem auditory nuclei of vertebrates. Annu Rev Physiol 61:497-519.

Quick DC, Kennedy WR, Donaldson L (1979) Dimensions of myelinated nerve fibers near the motor and sensory terminals in cat tenuissimus muscles. Neuroscience 4:1089-1096.

Raman IM, Bean BP (1997) Resurgent sodium current and action potential formation in dissociated cerebellar Purkinje neurons. J Neurosci 17:4517-4526.

Raman IM, Sprunger LK, Meisler MH, Bean BP (1997) Altered subthreshold sodium currents and disrupted firing patterns in Purkinje neurons of Scn8a mutant mice. Neuron 19:881-891.

Regehr WG (1997) Interplay between sodium and calcium dynamics in granule cell presynaptic terminals. Biophys J 73:2476-2488.

Reuter H, Porzig H (1995) Localization and functional significance of the $\mathrm{Na}^{+} / \mathrm{Ca}^{2+}$ exchanger in presynaptic boutons of hippocampal cells in culture. Neuron 15:1077-1084.

Rosenthal JJ, Bezanilla F (2002) A comparison of propagated action potentials from tropical and temperate squid axons: different durations and conduction velocities correlate with ionic conductance levels. J Exp Biol 205:1819-1830.

Rowland KC, Irby NK, Spirou GA (2000) Specialized synapse-associated structures within the calyx of Held. J Neurosci 20:9135-9144.

Salzer JL (2003) Polarized domains of myelinated axons. Neuron 40:297-318.

Sätzler K, Söhl LF, Bollmann JH, Borst JGG Frotscher M, Sakmann B, Lübke JHR (2002) Three-dimensional reconstruction of a calyx of Held and its postsynaptic principal neuron in the medial nucleus of the trapezoid body. J Neurosci 22:10567-10579.

Schwarz JR, Eikhof G (1987) Na currents and action potentials in rat myelinated nerves fibers at 20 and $37^{\circ} \mathrm{C}$. Pflügers Arch 409:569-577.

Shcherbatko A, Ono F, Mandel G, Brehm P (1999) Voltage-dependent sodium channel function in regulated through membrane mechanics. Biophys J 77:1945-1959.

Smith MR, Smith RD, Plummer NW, Meisler MH, Goldin AL (1998a) Functional analysis of the mouse Scn8a sodium channel. J Neurosci 18:6093-6102.

Smith PH, Joris PX, Yin TCT (1998b) Anatomy and physiology of principal cells of the medial nucleus of the trapezoid body (MNTB) of the cat. J Neurophysiol 79:3127-3142.

Smith SM, Bergsman JB, Harata NC, Scheller RH, Tsien RW (2004) Recordings from single neocortical nerve terminals reveal a nonselective cation channel activated by decreases in extracellular calcium. Neuron 41:243-256.

Southan AP, Robertson B (1998) Patch-clamp recordings from cerebellar basket cell bodies and their presynaptic terminals reveal an asymmetric distribution of voltage-gated potassium channels. J Neurosci 18:948-955. Spirou GA, Berrebi AS (1996) Organization of ventrolateral periolivary cells 
of the cat superior olive as revealed by PEP-19 immunocytochemistry and Nissl stain. J Comp Neurol 368:100-120.

Spirou GA, Brownell WE, Zidanic M (1990) Recordings from cat trapezoid body and HRP labeling of globular bushy cell axons. J Neurophysiol 63:1169-1190.

Taschenberger H, von Gersdorff H (2000) Fine-tuning an auditory synapse for speed and fidelity: developmental changes in presynaptic waveform, EPSC kinetics, and synaptic plasticity. J Neurosci 20:9162-9173.

Taschenberger H, Leão RM, Rowland KC, Spirou GA, von Gersdorff (2002) Optimizing synaptic architecture and efficiency for high-frequency transmission. Neuron 36:1127-1143.

Torkkeli PH, French AS (2002) Simulation of different firing patterns in paired spider mechanoreceptor neurons: the role of $\mathrm{Na}^{+}$channel inactivation. J Neurophys 87:1363-1368.

Traynelis SF (1998) Software-based correction of single compartment series resistance errors. J Neurosci Methods 86:25-34.

Trimmer JS, Rhodes KJ (2004) Localization of voltage-gated ion channels in mammalian brain. Annu Rev Physiol 66:477-519.

von Gersdorff H, Schneggenburger R, Weiss S, Neher E (1997) Presynaptic depression at a calyx synapse: the small contribution of metabotropic glutamate receptors. J Neurosci 17:8137-8146.

Wang LY, Gan L, Forsythe ID, Kaczmarek LK (1998) Contribution of the
Kv3.1 potassium channel to high-frequency firing in mouse auditory neurons. J Physiol (Lond) 509:183-194.

Waxman SG (1975) Integrative properties and design principles of axons. Int Rev Neurobiol 18:1-17.

Westenbroek RE, Merrick DK, Catteral WA (1989) Differential subcellular localization of the RI and RII $\mathrm{Na}^{+}$channel subtypes in central neurons. Neuron 3:695-704.

Wu LG, Westenbroek RE, Borst JGG, Catterall WA, Sakmann B (1999) Calcium channel types with distinct presynaptic localization couple differentially to transmitter release in single calyx-type synapses. J Neurosci 19:726-736.

Wu SH, Kelly JB (1993) Response of neurons in the lateral superior olive and medial nucleus of the trapezoid body to repetitive stimulation: intracellular and extracellular recordings from mouse brain slice. Hearing Res 68:189-201.

Wu XS, Sun JY, Evers AS, Crowder M, Wu LG (2004) Isoflurane inhibits transmitter release and the presynaptic action potential. Anesthesiology 100:663-670.

Zhang S, Trussell L (1994) Voltage clamp analysis of excitatory synaptic transmission in the avian nucleus magnocellularis. J Physiol (Lond) 480:123-136.

Zhou W, Goldin AL (2004) Use-dependent potentiation of Nav1.6 sodium channel. Biophys J 87:3862-3872. 